\title{
Cotton in ancient Sudan and Nubia
}

Archaeological sources and historical implications

Le coton en Nubie et au Soudan anciens: sources archéologiques et implications historiques

\section{Elsa Yvanez and Magdalena M. Wozniak}

\section{OpenEdition}

\section{Journals}

Electronic version

URL: http://journals.openedition.org/ethnoecologie/4429

DOI: 10.4000/ethnoecologie.4429

ISSN: 2267-2419

\section{Publisher}

Laboratoire Eco-anthropologie et Ethnobiologie

\section{Electronic reference}

Elsa Yvanez and Magdalena M. Wozniak, « Cotton in ancient Sudan and Nubia », Revue d'ethnoécologie [Online], 15 | 2019, Online since 30 June 2019, connection on 10 December 2020. URL : http:// journals.openedition.org/ethnoecologie/4429; DOI : https://doi.org/10.4000/ethnoecologie.4429

This text was automatically generated on 10 December 2020.

\section{(†) $९$

Revue d'ethnoécologie est mis à disposition selon les termes de la licence Creative Commons Attribution - Pas d'Utilisation Commerciale - Pas de Modification 4.0 International. 


\title{
Cotton in ancient Sudan and Nubia
}

\author{
Archaeological sources and historical implications \\ Le coton en Nubie et au Soudan anciens : sources archéologiques et implications \\ historiques
}

Elsa Yvanez and Magdalena M. Wozniak

\section{Introduction}

1 Cotton production was a well-known feature of Nubian agriculture as early as the end of the $1^{\text {st }}$ century CE, when Pliny the Elder mentioned in his Natural History "the woolbearing trees of Ethiopia" growing at the southern border of Egypt.

"Ethiopia, which borders upon Egypt, has in general no remarkable trees, with the exception of the wool-bearing ones, of which we have had occasion to speak in our description of the trees of India and Arabia. However, the produce of the tree of Ethiopia bears much stronger resemblance to wool, and the follicle is much larger, being very similar in appearance to pomegranate; as for the trees they are otherwise similar in every respect". ${ }^{1}$

Pliny the Elder, Natural History XIII, 28.

2 Later sources continued to mention the culture of cotton in the region until modern times. Never described on a very large scale, the production seems to have been quite limited. Writing in the $14^{\text {th }}$ and $15^{\text {th }}$ centuries, the medieval historian al-Maqrizi tells us that "there are a few cotton plantations in Nubia", in the region of Qasr Ibrim, from which the inhabitants "make rough cotton material" (after Al-Uswani, Vantini 1975: 605). Together with dates, grain, dromedaries, iron tools, cattle and slaves, cotton was an important part of the local economy, maybe involved in exchanges and payments of customary dues at the Egyptian border (Vantini 1975: 645).

Despite these clear historical accounts, cotton wasn't at first recognised in the archaeological assemblage by the first explorers of the Nubian past, more familiar as they were with the plentiful Egyptian linen textiles. Upon the discovery of the well preserved graves of Karanog in 1908, the archaeologists noted that "the bodies were wrapped in regular shrouds of rather heavy undyed linen cloth of a yellowish colour" 
(Woolley \& Maciver 1910: 27). Working in Sudan during the following years, Francis Ll. Griffith and Grace M. Crowfoot had the opportunity and acumen to recognise cotton in the very decayed textile samples found by Georges A. Reisner in Meroe. Following John W. Crowfoot's early intuition that cotton had been an important source of wealth for the Meroitic kingdom (Crowfoot 1911: 37), Francis Ll. Griffith and Grace Crowfoot collected and sent textile samples from Karanog and Meroe to be tested in England ${ }^{2}$. Their joint investigation, published in 1934 in the Journal of Egyptian Archaeology, set the basis of textile research in ancient Sudan and Nubia (Griffith \& Crowfoot 1934). Almost a century later, recent studies have confirmed Crowfoot's hypotheses:

"Meroe cotton was grown in the country - and woven there, then - of course"

(ibid: 12) and "[it] goes far to explain the wealth of Meroe at this time" (Crowfoot

1911: 37).

4 In the dry regions of Central Sudan and Nubia, the discovery of cotton opened many questions, since it is a plant more often portrayed as a thirsty crop best suited to subtropical climates. Following Pliny's description and his mention of Indian cotton, the origin of the Nubian products has been open to debate and constituted the heart of the research for several years (e.g. Watson 1977, Gervers 1990). Was cotton culture introduced in the Middle Nile valley from the Indian subcontinent or was it developed in Sudan itself from indigenous trees? Going further and acting upon Crowfoot's proposition, it now becomes essential to also explore the relation between cotton production and its socio-economic environment to understand its impact on the Meroitic world. Consecutive to its introduction, what were the implications of such a demanding crop on the local economy? How did the weavers, more familiar with linen and wool, reacted to this new fibre? And what role did cotton play in a changing textile landscape from Late Antiquity to medieval times?

5 Many new data have come to light since these early pioneers: our textile corpus from Nubia and Sudan has grown to now count many thousands of fragments from diverse sites along the Nile, covering the periods from the first Kushite kingdom of Kerma ( $c$. 2500-1500 BCE) to the Ottoman occupation of Nubia and modern days ${ }^{3}$. Our understanding of textile production has also branched out from the textiles themselves to incorporate the tools needed for their manufacture and the many representations of people wearing diverse garments. Indirect evidence as they may be, both tools and iconography can bring valuable information to our present research on cotton and are essential aspects of past textile production (Bouchaud et al. this volume). The study of ancient fibres has also seen the recent multiplication of archaeobotanical analyses, which brought answers to long lasting questions and deepened our knowledge of agricultural exploitation in ancient Sudan. This rich body of evidence naturally lends itself to a multidisciplinary approach, at the core of the recent methods developed by textiles studies. Cotton production is now the subject of a renewed interest in the archaeology of the ancient world, from India to Africa, and general trends are starting to emerge (Wild et al. 2008, Bouchaud et al. 2018). Opening new lines of enquiries, this present volume offers a perfect opportunity to define the present state of knowledge on ancient cotton production and its historical implications in Sudan and Nubia from the Meroitic to the medieval periods (Figure 1). 
Figure 1: Map of Sudan showing the major archaeological sites with discoveries of cotton fabrics and textile tools. Map E. Yvanez/Google Earth

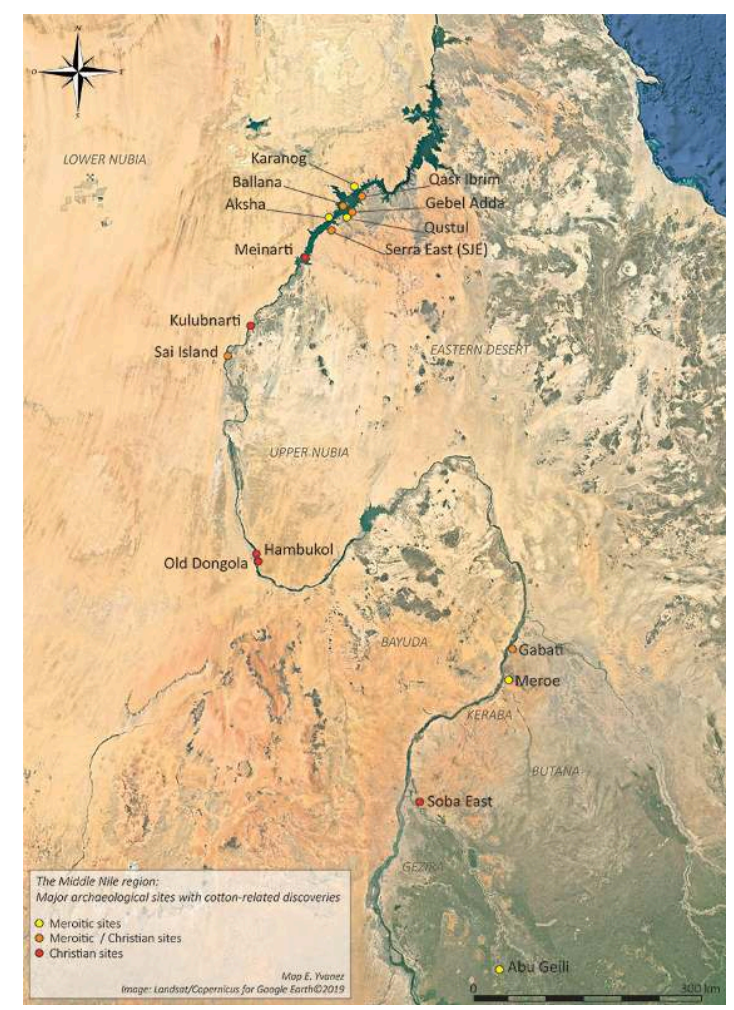

Map E. Yvanez/Google Earth

\section{Meroitic period}

The Meroitic kingdom developed from Central Sudan at the very beginning of the $3^{\text {rd }}$ century BCE. Successors to the other Kushite kingdoms of Kerma (c. 2500-1500 BCE) and Napata (c. 760-300 BCE), the Meroitic kings and queens shifted the centre of power southward, from the Dongola Reach region to the "Island of Meroe" (actual Central Sudan). It was the location of the capital city of Meroe and was bordered by the Blue Nile, the main Nile, the Atbara river, and the many wadis of the Bayuda desert. During the following five centuries, they extended their power over a vast territory covering $1500 \mathrm{~km}$ of the Nile valley, from Northern Nubia to the fertile plains of the South in the Gezira region. The shifting borders of this empire included very diverse populations composed of sedentary, semi-nomads and nomadic groups, settling along the rivers and in the adjacent deserts ${ }^{4}$. The many monuments built by the Meroitic royal family, the nobles, and the elite show people dressed on the one hand in lavish costumes and adorned with elaborate jewellery, or on the other hand covered by simpler garments. Thanks to the hyper-arid climatic conditions of Nubia, hundreds of Meroitic graves and a few settlements have delivered a remarkably rich assemblage of archaeological textiles ${ }^{5}$, opening an interesting dialogue with the surrounding iconography. While textile finds are very rare for the Napatan period and scarce for the first phase of Meroitic history, their number increases dramatically from the $1^{\text {st }}$ century CE onward. Coincidentally, this now plethoric material is overwhelmingly made of cotton fibre, in a clear demarcation from earlier textiles made of linen and wool. Meroitic textiles and 
dress practices are therefore closely intertwined with cotton production, placing cotton at the heart of the economy and culture of this ancient African kingdom.

\section{Sources}

\section{Archaeobotanical remains}

7 In Sudan and Nubia, cotton is first attested from the very beginning of the textiles chaine opératoire, from the cultivation of the plant itself and the following stages of the fibres' preparation. The discovery of cotton remains at Afyeh, dated to $2600-2400 \mathrm{BCE}$ (Chowdhury \& Buth 1970, 1971, 2005), has clouded the history of Sudanese cotton for a long time. However, recent studies have undermined these results, stressing the inadequate sampling and dating processes behind this hypothetical early occurrence (Bouchaud et al. 2018: 386). Recent work has instead focused on new archaeobotanical discoveries, highlighting the cotton remains made available by recent settlement excavations (Fuller 2014: 172-173, Fuller 2015: 14, Bouchaud et al. 2018) (Figure 2).

Figure 2: Archaeobotanical remains of Meroitic cotton (Qasr Ibrim: data collected from Clapham \& Rowley-Conwy 2009: table 26.2: 248; Hamadab: personal communications from D. Fuller and P. Wolf (analyses ongoing), mentioned in Fuller 2014; Mouweis: C. Bouchaud et al. 2018: 395-397).

\begin{tabular}{|c|c|c|}
\hline Site & Remains & Date \\
\hline Qasr Ibrim & $\begin{array}{l}\text { Desiccated and charred. Complete bolls, whole and } \\
\text { fragmented seeds, seeds with fibers, empty capsules, } \\
\text { cotyledons. }\end{array}$ & $\begin{array}{l}\text { From the Roman occupation (c. } 25 \text { BCE-100 CE) to the } \\
\text { abandonment of the site in } 1812 \text {. } \\
\text { majority of specimen: } 1^{\text {st }-6^{\text {th }} \text { c. CE }}\end{array}$ \\
\hline Hamadab & Charred. Fragmented seeds. & $1^{\text {st }-3^{\text {th }}}$ c. CE \\
\hline Mouweis & $\begin{array}{l}\text { Charred. } \\
\text { Seeds (fragmented and whole), seed coats, cotyledons. }\end{array}$ & 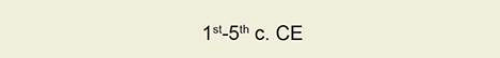 \\
\hline
\end{tabular}

Thanks to exceptional climatic conditions, the fortress of Qasr Ibrim in Lower Nubia has provided researchers with a great quantity of botanical remains showing the agricultural evolution of Nubia from c. $700 \mathrm{BCE}$ to $1800 \mathrm{CE}^{6}$. Among this material, desiccated and charred cotton remains (Figure 3) composed of complete bolls, whole and fragmented seeds, seeds with attached fibres, empty capsules, and cotyledons, are particularly significant (Clapham \& Rowley-Conwy 2006a, 2006b, 2007, 2009). Early finds dated to the Roman and Classic Meroitic periods (c. 25 BCE - $100 \mathrm{CE}$ ) are relatively rare and mostly formed by seeds and seeds with fibres. The following Late Meroitic and Post-Meroitic periods show a marked increase in the number of finds, now including capsules and complete bolls as well. Together with the many textiles found on the site, these archaeobotanical remains confirm the local cultivation and processing of cotton fibres in the surrounding area as early as the beginning of $1^{\text {st }}$ century CE. A recent archaeogenomic study has shown that Qasr Ibrim cotton belongs to the Gossypium herbaceum variety, native to Africa, and was therefore resulting from an indigenous domestication process rather than from the adoption of Gossypium arboreum coming from the Indian subcontinent (Palmer et al. 2012). Interestingly, this early Nubian cotton already exhibited traits showing its adaptation to extreme environmental stress, particularly dehydration (ibid: 2035). Far from being unsuited to the arid climate of Nubia, as early researchers argued to explain its Indian origin, Qasr Ibrim cotton was in fact well integrated in the local irrigated agricultural system and belonged to a larger dynamic of plant domestication and diffusion across the African savannahs ${ }^{7}$. 
Figure 3: Archaeobotanical remains from Qasr Ibrim: cotton seeds with lint attached (Meroitic), empty cotton calices (medieval), and complete cotton ball (Meroitic)

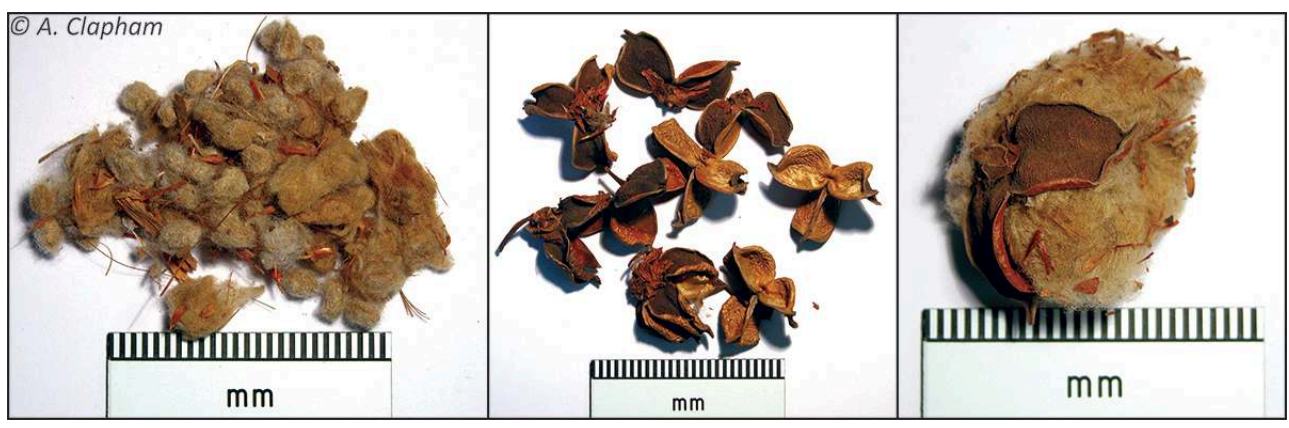

Photos courtesy of Alan Clapham

Other archaeobotanical remains of cotton have been found further south in the Island of Meroe, in the settlements of Hamadab and Mouweis. Ongoing research in the establishment of Hamadab has revealed fragmented cotton seeds among other plant remains found burned in food storage areas (Fuller 2014: 173). Dated to the Late Meroitic period, they show the local processing of cotton fibres, presumably cultivated nearby, and the later discard of its by-products. Not far from Hamadab, the Meroitic town of Mouweis also revealed cotton seeds, seed coats and cotyledons, all of them charred and discovered in thin ashy layers containing the rebuts of craft and domestic activities conducted in the mixed industrial sector 3 (Bouchaud et al. 2018: 395-397). The development of archaeobotanical sampling and studies in the Island of Meroe will continue to document this growing body of evidence for cotton cultivation in Central Sudan.

\section{Textiles}

Despite Crowfoot and Griffith's convincing study on the use of cotton in the local Meroitic textile industry, the fabrics discovered in Karanog and Meroe continued to be seen as foreign productions until the mid-70s. In 1955, Anthony J. Arkell chooses to interpret them as Indian imports (Arkell 1955: 166). As for Peter L. Shinnie and William Y. Adams, they both saw the elaborate tapestry décors found at Karanog as proofs of their Egyptian origin (Shinnie 1967: 129, Adams 1977: 371). Initiated by the 1960's rescue excavations of Lower Nubia, the discovery of several large textile corpora dated to the Meroitic, Postmeroitic and medieval periods radically changed this view and prompted the first large scale textile analyses in Sudanese archaeology. Thousands of textiles were unearthed by the Scandinavian Joint Expedition to Nubia between Faras and Gammai, and partly published in 1975 in a dedicated catalogue, Lower Nubian Textiles, by Ingrid Bergman (Bergman 1975). A few years later, Christa Mayer-Thurman and Bruce Williams published their exhibition catalogue, Ancient Textiles from Nubia, based on the extensive collection retrieved from the elite graves of Ballana and Qustul (Mayer Thurman \& Williams 1979). Finally, Elisabeth Crowfoot and Nettie K. Adams dedicated most of their energy to the tens of thousands of textiles found in refuse deposits along the alleyways and buildings of Qasr Ibrim ${ }^{8}$. Their work at Qasr Ibrim was soon pursued by John-Peter and Felicity Wild, who studied the Napatan and Meroitic fabrics unearthed in the more recent excavation of Pamela Rose and the Egypt Exploration Society (Wild \& Wild 2006, 2008, Wild 2011). Building on these pioneering studies, ongoing work is currently conducted on these and other finds, from Nubia and 
Central Sudan. Started by the author (Elsa Yvanez) as part of her doctoral research, a growing database now counts over 1000 textile references, documenting both single specimen and full groups of textiles dated to the Meroitic and Postmeroitic periods, from the $1^{\text {st }}$ century BCE to the mid- $6^{\text {th }}$ century $\mathrm{CE}^{9}$. The fabrics come from a total of 34 sites, $70 \%$ from funerary contexts and $30 \%$ from the urban settlement of Qasr Ibrim ${ }^{10}$. The overwhelming majority of fabrics have been discovered in Nubia, for reasons pertaining to climatic conditions and the historiography of archaeological research in Sudan. The textiles are mainly re-used items of clothing or multi-purpose cloths, which were placed in the graves as shrouds (Figure 4) or as blankets to receive the body of the deceased.

Figure 4: Remains of cotton textiles (circled in yellow) on the naturally mummified body of a woman from Aksha, grave 38

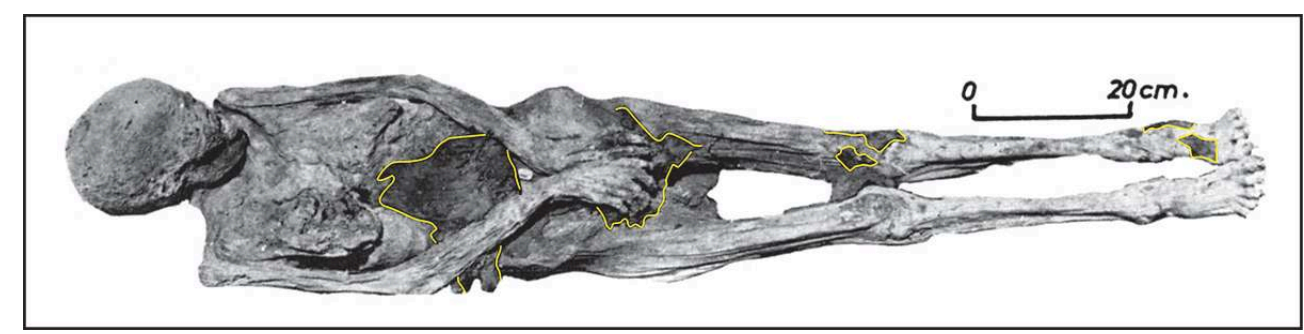

Reproduced from Vila 1967: fig. 288, 321

Of this important corpus, c. $40 \%$ of textiles were made of cotton (Figure 5) ${ }^{11}$. The fibre appears first in the textiles from Aksha, a Lower Nubian cemetery, dated to the end of the $1^{\text {st }}$ century $\mathrm{BCE}$ or to the very beginning of the $1^{\text {st }}$ century $\mathrm{CE}$. It then becomes particularly prominent during the following centuries, dominating the textile corpus dated to the Late Meroitic phase $\left(2^{\text {nd }}-3^{\text {rd }}\right.$ centuries CE). The fibre is present in every major Meroitic cemetery that benefited from a good preservation of organic material: Sai, Aksha, Karanog, Qustul, Ballana, Qasr Ibrim, Meroe, and Gebel Adda ${ }^{12}$. Several of these sites show very high percentage of cotton, up to $100 \%$ of the preserved textile assemblage from Karanog for example. Cotton is also attested in the cemeteries of Abka, Ashkeit, Gabati, Sahaba, Sedeinga, Semna South, Serra East, Serra, and Shablul. Its presence is also strongly presumed at Abu Simbel, Berber, Gammai, Kassinger Bahri, Nag-Shayeg and Wadi es-Sebua ${ }^{13}$. 
Figure 5: Histogram tracking fibre frequency on several Meroitic sites

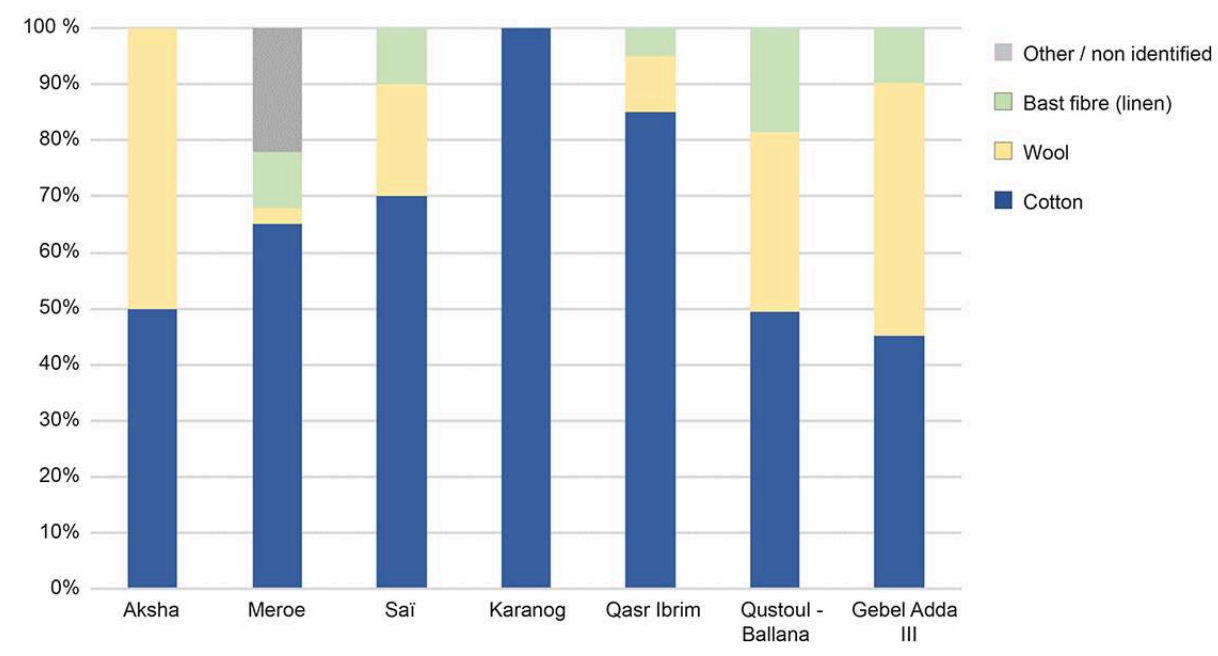

Graph E. Yvanez

Tools

11 Another type of archaeological objects to consider are the textile implements, the tools, which helped ancient craftsmen and craftswomen process the raw fibres into threads, weave them into fabrics, and finally sew them into garments and furnishing. Different categories of tools reflect the various stages of the textiles chaine opératoire:

12 - Spinning tools: spindle and spindle whorls (Figure 6a)

- Weaving tools: loom weights (Figure 6b), bone picks (so-called "weaving picks"), and to a lesser extent weaving combs, shuttles and thread beaters. The frequent findings of piriform clay loom weights indicates the use of the warp-weighted loom.

- Sewing tools: needles. 
Figure 6a: Ceramic spindle whorl with incised concentric circles. Mouweis, Mws10-Ka031-05a

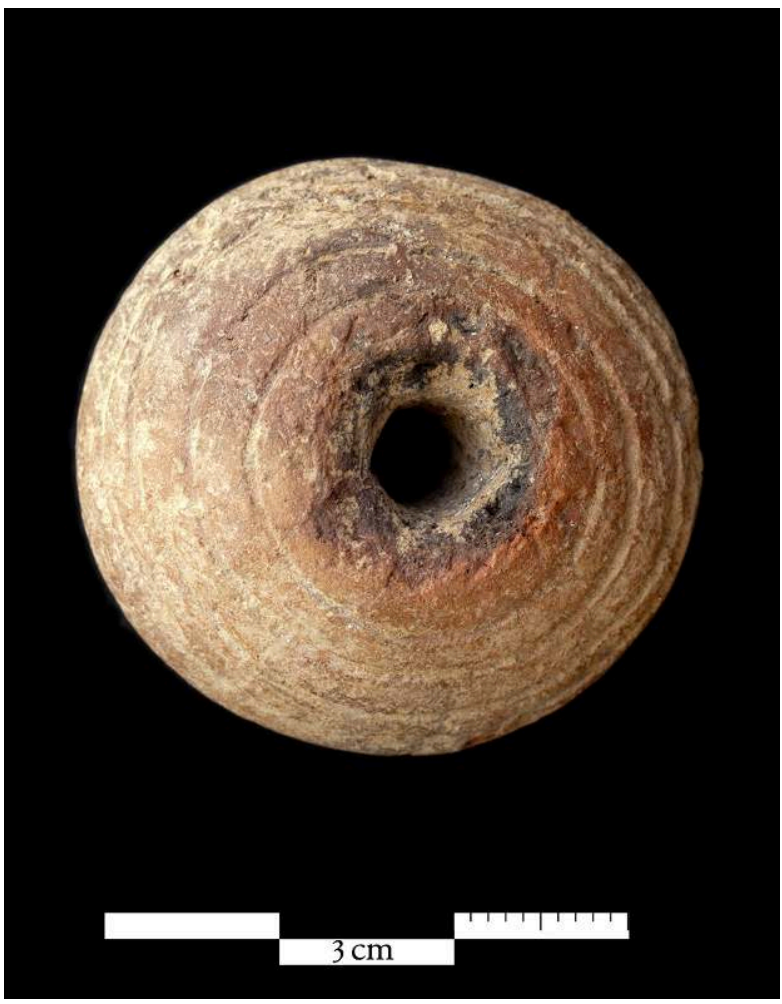

(c) Musée du Louvre-Mission archéologique de Mouweis-Olivier Cabon

Figure 6b: Group of clay loom weights. Mouweis, Mws09-Ka025-09poids-0C09

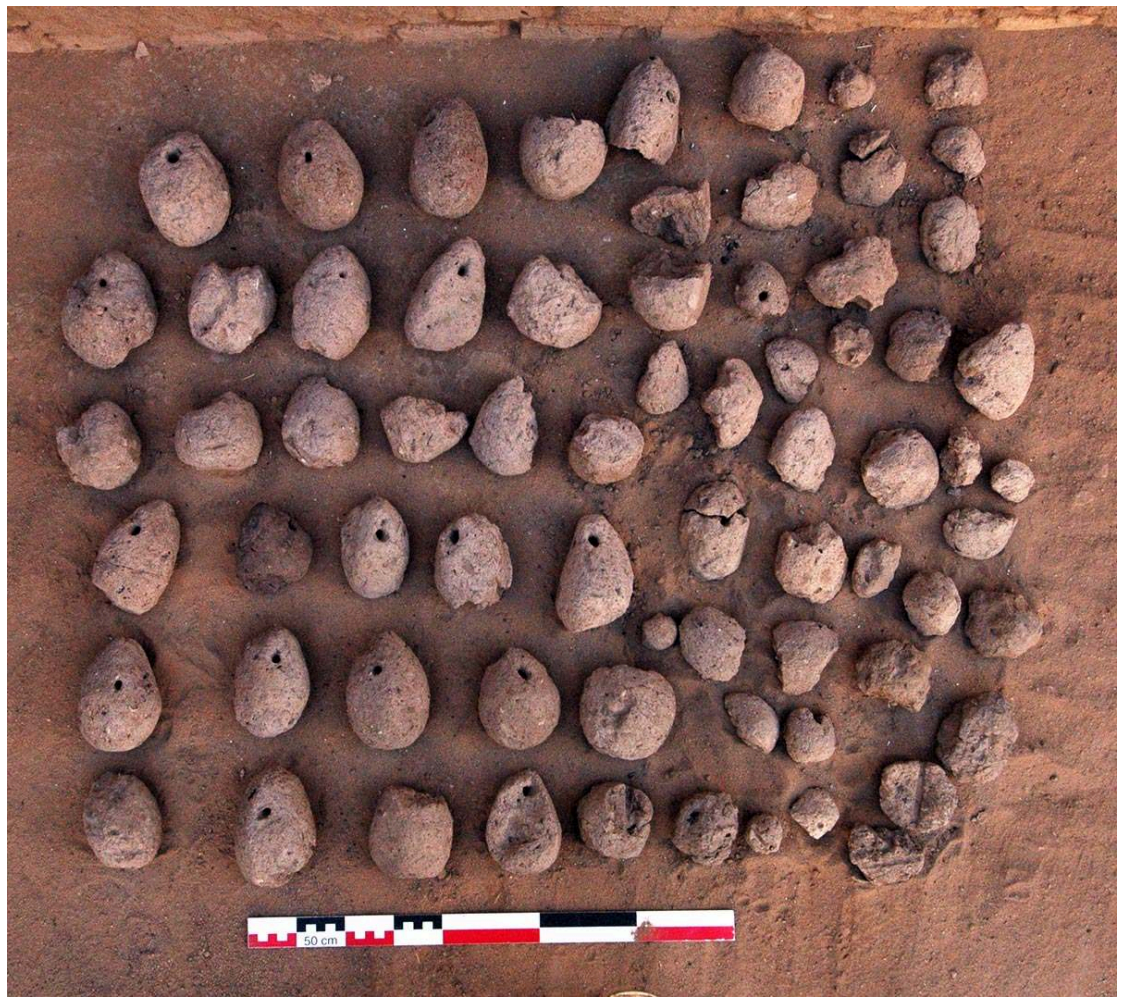

(c) Musée du Louvre-Mission archéologique de Mouweis-Olivier Cabon 
The numerically most important group of tools is formed by spindle whorls, with over a thousand specimen recorded so far from Lower and Middle Nubia, Central Sudan and from the Gezira/Blue Nile regions (Yvanez 2016a). The corpus shows a clear distinction between North and South. In Nubia, the spindle whorls are generally made of turned wood, and less often of bone, following a similar typology to that of their Egyptian counterparts during the same period. However, in Central Sudan and in the Gezira the spindle whorls are largely made of baked clay.

\section{Iconography}

The final type of relevant source for the Meroitic period is iconography. Numerous iconographic documents display various people wearing different costumes. Mostly commissioned by the royal family and members of the nobility, these representations are present in carved or painted scenes decorating temples, funerary chapels, and fine ware ceramics. They also appear on sculptures, private stele, decorated bronze objects (Figure 7), and jewellery. They are particularly helpful to document the different pieces of clothing worn by the elite and their arrangement in specific outfits, as well as the components of the royal ceremonial costume for which we know no preserved fabric (Yvanez 2018a, Török 1990). Less frequently, wall carvings ("graffiti") show other members of the population, wearing mid-length skirts or loincloths.

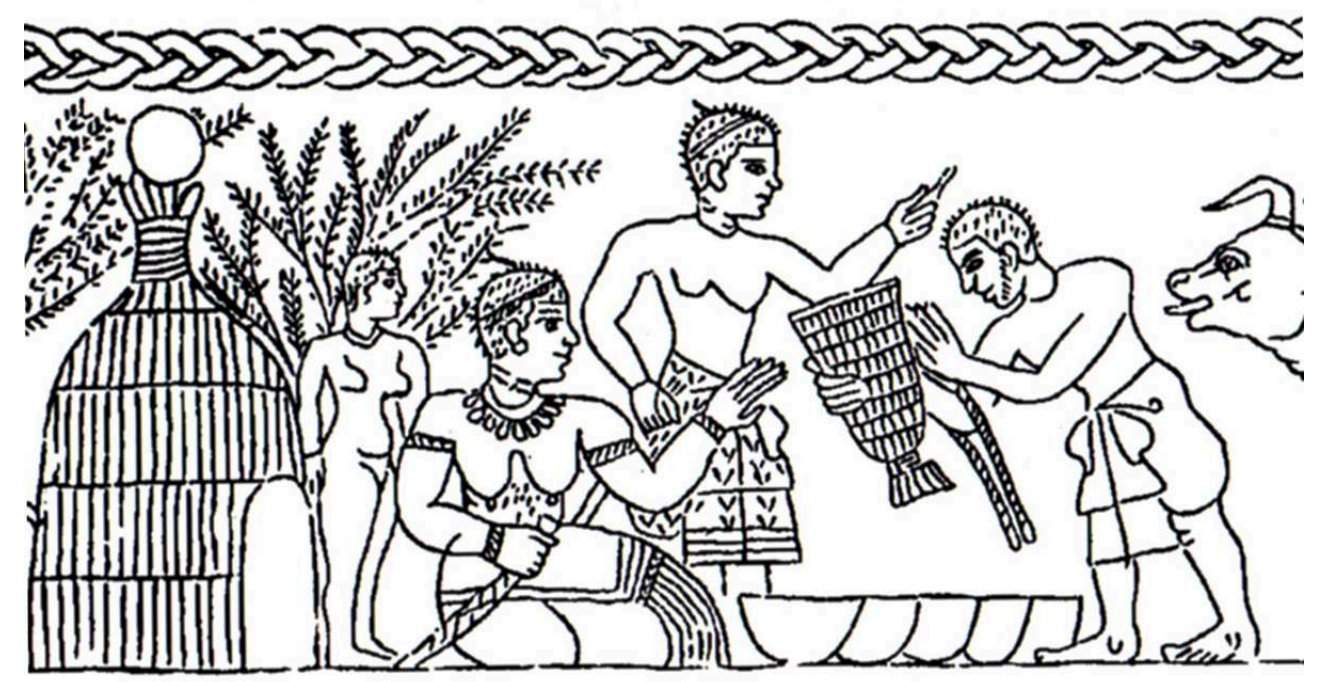

Reproduced from Soudan Royaumes sur le Nil 1997: n453, 382

The available data pertaining to cotton production in Meroitic Sudan covers a wide array of sources, each of them bringing their own kind of information, challenges and research questions. All together, they spread over the entire span of the Meroitic kingdom and six centuries of Sudanese history, from the southern plains of the Gezira to the desert of Nubia. They offer the opportunity to follow cotton production from the cultivation of the plant to the final interment of the cloths, through the many stages of fibre processing, textile manufacture, and use and re-use of the fabrics. They also allow 
us to apprehend the value of cotton as a cash crop potentially playing an important role in the economic and trading systems of Meroitic Sudan. A century after Crowfoot, a multi-layered approach encompassing this entire body of data can truly confirm the important role of cotton in the growth of "the wealth of Meroe" (Crowfoot 1911: 37).

\section{Historical implications}

Because of this very importance, studying Meroitic cotton production quickly equates to studying the entire textile chaîne opératoire and its economic and social implications. Such an enterprise would naturally exceed the scope of this article. We will therefore limit our investigation to four questions, delineating the state-of-the-art of each subject in order to offer a sound base for future research.

\section{Where was cotton cultivated?}

17 Archaeobotanical, textile and tool finds all appear to be concentrated around two main poles: Lower Nubia in the North, particularly in the region of Qasr Ibrim, and Central Sudan in the South (see Figure 1). This recording situation is partly due to the history of archaeological research in Sudan, which focused most of its efforts along these parts of the Nile course (Maillot 2017). It also presumably results from a poorer preservation of organic remains in regions such as the Dongola reach, the $4^{\text {th }}$ cataract, or the Gezira $^{14}$, which might explain the absence of textile remains from the Meroitic cemetery of Kerma for example. Nonetheless, these two poles reflect the technological division within the corpus of spindle whorls - wood in Lower Nubia, ceramic in Central Sudan and the Gezira ${ }^{15}$ - which could indicate different fibre production centres. This hiatus between North and South seems to mirror the data brought by archaeobotany, which places cotton cultivation in the two same areas: the region surrounding Qasr Ibrim/Karanog in Lower Nubia and the Island of Meroe in Central Sudan.

Focusing our attention on the southern parts of the Meroitic kingdom, a concentration of ceramic spindle whorls exhibiting extremely similar traits is easily noticeable over a large territory, from the city of Meroe to the banks of the Blue Nile at Abu Geili, passing through the royal establishments of Mouweis, el-Hassa, and Hamadab, and the Gezira site of Saqadi (see Appendix 1 and Fig. 1). They generally come from contexts dated to the Late Meroitic period, c. 200-300 CE. Together, they represent a numerically important corpus of spinning tools, amounting to several thousands of objects ${ }^{16}$. For example, about 3000 spindle whorls were reported to have been found at Abu Geili (only 1000 specimen were kept, the others were reburied on site), and 228 were listed in the excavation inventories of Meroe ${ }^{17}$. These spindle whorls are almost exclusively made of ceramic, with very few exceptions made of stone or unbaked clay. The ceramic ones share a common typology, revealing the clear standardisation of the tool itself as well as of the spinning process, throughout this very large territory (Yvanez 2016a: 158-171). A simple comparison between the ceramic spindle whorls from Abu Geili and Meroe shows a strikingly consistent typology (see below, Figure 9): the same shape, the same size, and most importantly where spinning is concerned, the same weight. Overall, the average diameter varies within $4 \mathrm{~mm}$ between sites, and the difference between average mass is within $5 \mathrm{~g}$.

These two spindle whorls with sorghum motives (Figure 8), one from Meroe and the other from Abu Geili, are good examples of the shared repertoire of decorative patterns 
on this type of tool. They also illustrate another plant of the "savannah package" essential to the Meroitic economy (Fuller 2014).

Figure 8: Ceramic spindle whorls decorated with sorgho patterns, from Abu Geili (left, no SNM number) and Meroe (right, SNM 604)

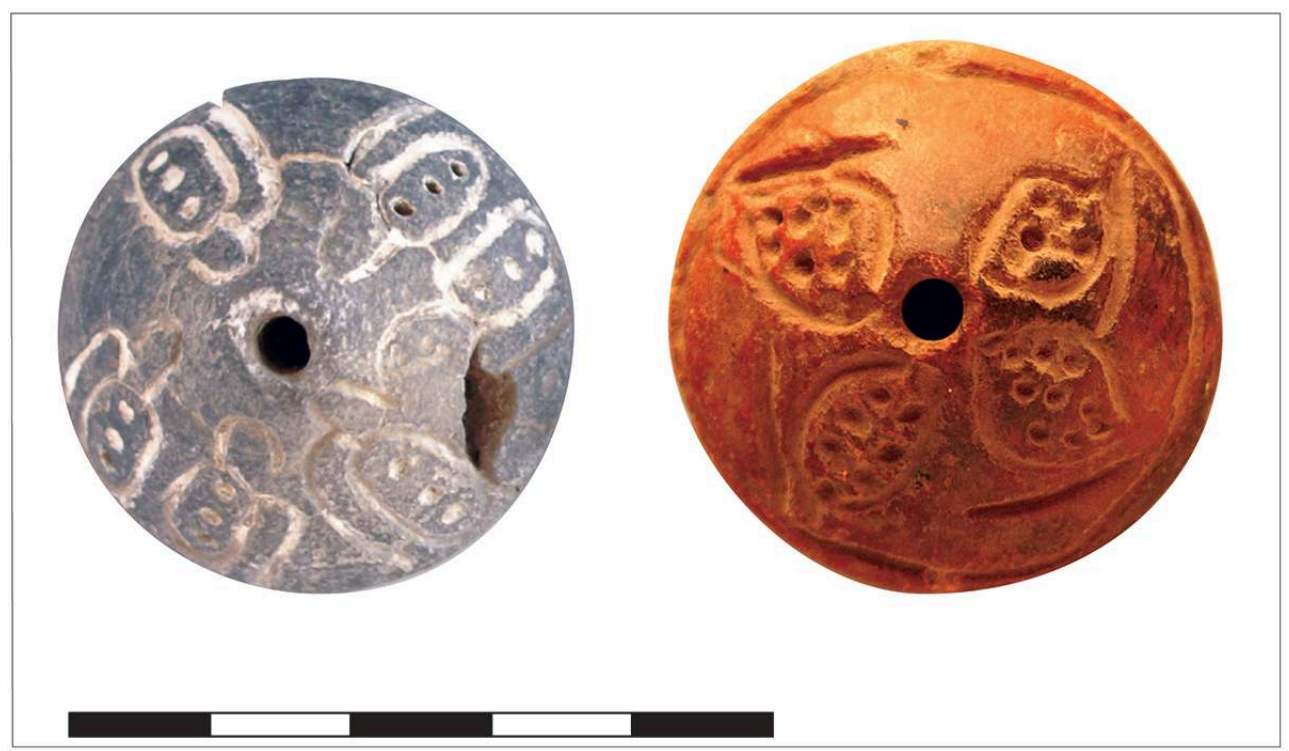

Photos E. Yvanez, courtesy of the Sudan National Museum

On the other side of the geographical spectrum, the Nubian spindle whorls exhibit a slightly different typological profile. Predominantly made of wood, they mostly come from the region downstream of the $2^{\text {nd }}$ cataract, from Ballana, Qustul, Arminna West, Gebel Adda, Karanog and Qasr Ibrim, as well as from the island of Tila (see Appendix 1). Dated to the Late Meroitic and Post-Meroitic period, these spindle whorls form a somewhat smaller corpus of c. 140 specimens, awaiting a reappraisal of the many more unstudied objects found at Qasr Ibrim ${ }^{18}$. A preliminary typological survey shows a homogenous group following the same shape, dimensions and technical characteristics. The wooden spindle whorls are all made of turned wood, shaped as a disc with a slightly domed or hemispheric profile, and often decorated with concentric circles around their perimeter and smaller dotted circles on their surface (Yvanez 2018a: fig. $1 \mathrm{a}, 82)$. In that regard, the Lower Nubian spindle whorls follow the contemporaneous model generally observed in Roman Egypt (Rutschowscaya 1986: 44-52). Here represented by the 30 specimen found in the graves of Karanog, the Lower Nubian spindle whorls show over all a smaller calibre than the tools used in the Island of Meroe and the Gezira regions. Despite a similar average diameter, they are much thinner and significantly lighter than their ceramic counterparts (Table 2). 
Figure 9: Comparison of spindle whorls' average dimensions between Abu Geili (Blue Nile/Gezira, 422 specimen studied), Meroe (Central Sudan, 34 specimen studied), and Karanog (Lower Nubia, 30 specimen)

\begin{tabular}{|l|c|c|c|}
\hline \multicolumn{1}{|c|}{ Site } & Abu Geili & Meroe & Karanog \\
\hline Material & ceramic & ceramic & wood \\
\hline Diameter & $38 \mathrm{~mm}$ & $39 \mathrm{~mm}$ & $37 \mathrm{~mm}$ \\
\hline Thickness & $23 \mathrm{~mm}$ & $21 \mathrm{~mm}$ & $14 \mathrm{~mm}$ \\
\hline Hole diameter & $4.5 \mathrm{~mm}$ & $5 \mathrm{~mm}$ & $4 \mathrm{~mm}$ \\
\hline Weight & $29 \mathrm{~g}$ & $25 \mathrm{~g}$ & $12 \mathrm{~g}$ \\
\hline
\end{tabular}

Despite their differences, both wooden and ceramic spindle whorls could have been used to spin cotton. They fall within the medium-light category of spinning tools, which would in theory have been suited to spin short fibres into thin to medium threads (Barber 1992: 52) ${ }^{19}$. In Meroitic Sudan, cotton threads are generally around 1 $0.5 \mathrm{~mm}$ of diameter, which seems to fit the range of these spindle whorls. Both in Lower Nubia and Central Sudan, remains of raw fibres and fibre processing tools offer a coherent picture of cotton production. However, we should remain cautious as to the use of this data alone. Many unknown element remain, such as the weight and length of the spindle or the presence of a secondary treatment on the spindle whorl itself (i.e. with a resin ${ }^{20}$, which could have both influenced the complete weight of the tool. Textiles and tools aren't also necessarily contemporaneous on every site. In both Qasr Ibrim and Central Sudan, spindle whorls seem to be overwhelmingly dated to the later phase of the Late Meroitic period, therefore two to three centuries younger than the first cotton finds. A finer chronological attribution of the tools and textiles would be necessary before concluding that the spindle whorls were used without doubt to spin the very cotton found on the sites. Despite this reservation, it would be natural to assume that cotton processing, spinning, weaving and consumption of textiles could have occurred in the same location, at least on several sites in the main production areas. It is clearly attested at Qasr Ibrim, where a complete spindle, preserved with its spindle whorl and top hook, was found still loaded with spun yarn (Wild \& Wild 2014: 75). The thread was made of cotton, in a very hard S-twist, and is in every way similar to the yarn observed in Qasr Ibrim Meroitic textiles. It joins the many similar spindle whorls and spindles, the hundreds of cotton textiles, and the archaeobotanical remains showing different stages of cotton processing found on the site. Together, this corpus presents a coherent picture of the cotton textiles chaîne opératoire at Qasr Ibrim, from the processing of raw material to the use and discard of the final fabrics.

In any case, it is important to note that the archaeological data fits our knowledge of the climatic and agricultural requirements of cotton cultivation. A very thirsty crop, cotton grows best in tropical and subtropical climate, but cannot thrive with waterlogged roots or get wet during maturation (Fuller 2008: 4-6). As a result, the plant could not be cultivated along the Nile River where the annual flooding coincided with its growing and maturing season. Cotton needs to be cultivated on higher terraces of the Nile, away from the river, and irrigated with a shaduf or a saqia (Wild et al. 2007, Fuller 2014: 172-174). Its exploitation in the very dry lands of Lower Nubia was only possible thanks to the combined plant's adaptation mechanisms, helping it to tolerate partial dehydration, with the effective management of irrigation (Wild et al. 2007: 16). As a summer crop however, cotton belongs to a group of species called "the savannah package", most probably originating from the humid savannahs of the south and southeast of Sudan, i.e. in the Kordofan or the Gash Delta, both close to the Gezira (Fuller 
2014). The Gezira region, especially in Abu Geili's area along the Blue Nile and the Dinder River, offered fertile soil, enough precipitations, and several wadis providing natural irrigation, so was therefore especially well-suited to cotton cultivation. This favourable environment could explain why Abu Geili and surrounding settlements seem to have specialised in thread production, as shown by the thousands of spindle whorls recovered on the site (Yvanez 2016a: 171-174). In Central Sudan, cotton could have been grown along the Atbara River and the many seasonal wadis crossing the Butana desert with the help of minimal irrigation (Fuller 2014: 172). Interestingly, Hamadab, where cotton remains have been found, is located at the very mouth of the important Wadi el-Hawad and its fertile delta. This hypothesis is strengthen by the Ezana inscription, which recounted in c. 350 CE the destruction of "provisions of grain and cotton" by the Axumite armies in the Butana or at the junction of the Atbara river (Griffith \& Crowfoot 1934: 7) ${ }^{21}$.

23 Based on this information, we can propose three different locations for Meroitic cotton production: in Lower Nubia in the region of Qasr Ibrim, in Central Sudan along the Atbara River and seasonal wadis in the Butana hinterlands, and in the Gezira along the Blue Nile and the Dinder rivers. Further archaeobotanical discoveries would help refining this preliminary map, hopefully revealing the location of cotton domestication in Africa ${ }^{22}$.

\section{What was cotton used for?}

The study of Meroitic cotton production is a very rewarding enterprise. Unlike so many places in the world, hundreds of beautifully preserved fabrics paint a vivid and lively image of textile manufacture, full of colourful ornaments and unique local traditions. Rare however are the fully complete pieces: placed in a grave with the body of the deceased or left in rubbish deposits in long-lived settlements, textiles are generally fragmentary. In many instances, it is therefore impossible to determine their original function. However, the substantial corpus of cotton textiles indicates that this fibre was primarily used for clothing and for specific furnishing pieces.

Both clothing and furnishing pieces show similar technical characteristics, common to virtually all cotton textiles in Meroitic Sudan. We chose to illustrate their main characteristics by using examples of textiles fragments found in Lower Nubia, in the cemetery of Karanog ${ }^{23}$. The fibres (Figure 10) were spun in -S, i.e. in a counterclockwise direction, with resulting threads showing a very strong torsion, sometimes even overspun. It is particularly true of the warps, which needed to be strong enough to support the heavy loom weights of the warp-weighted loom. 
Figure 10: Cotton threads from Karanog, magnification x225 (๔ DinoLite hand-held microscope)

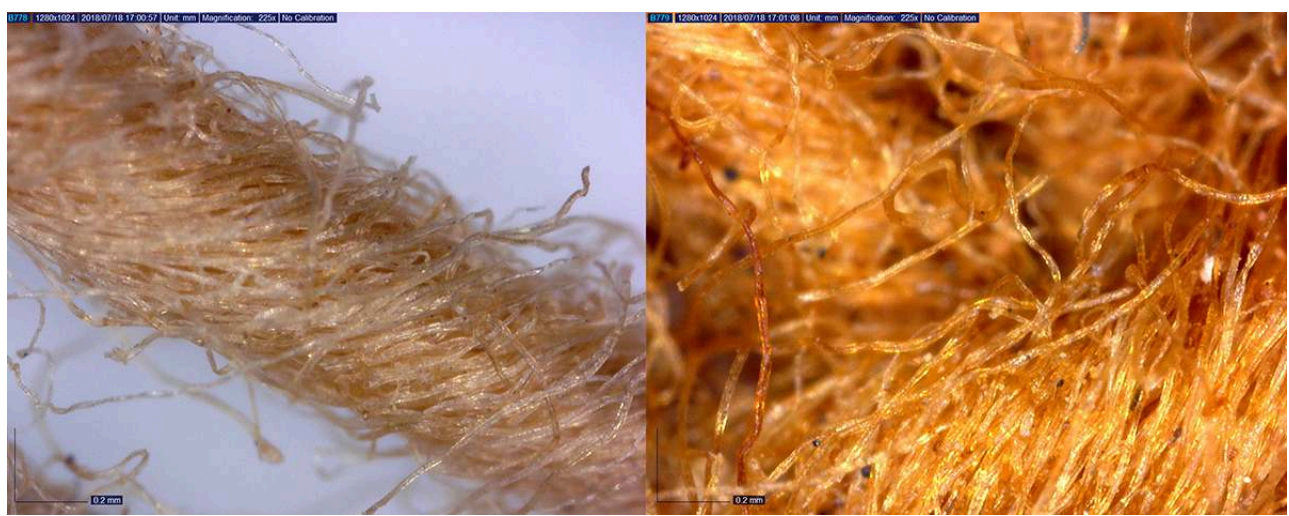

Courtesy of Penn Museum, image E7511.S.1, photo E. Yvanez

They are assembled in a plain tabby weave, in a simple $1 / 1$ ratio or in a half-basket or basket version (1/2,2/1, 2/2 ratio). The weave reduction varies from fabric to fabric but generally remains quite balanced within the same piece, showing a typical reduction around 10 threads $/ \mathrm{cm}^{2}$ in each system (warp and weft). This low density can be explained by the important diameter of the threads and the openness of the weave, which is rarely packed very tight (Figure 11).

Figure 11: Cotton plain weave from Karanog, magnification x50 (๑ DinoLite hand-held microscope)

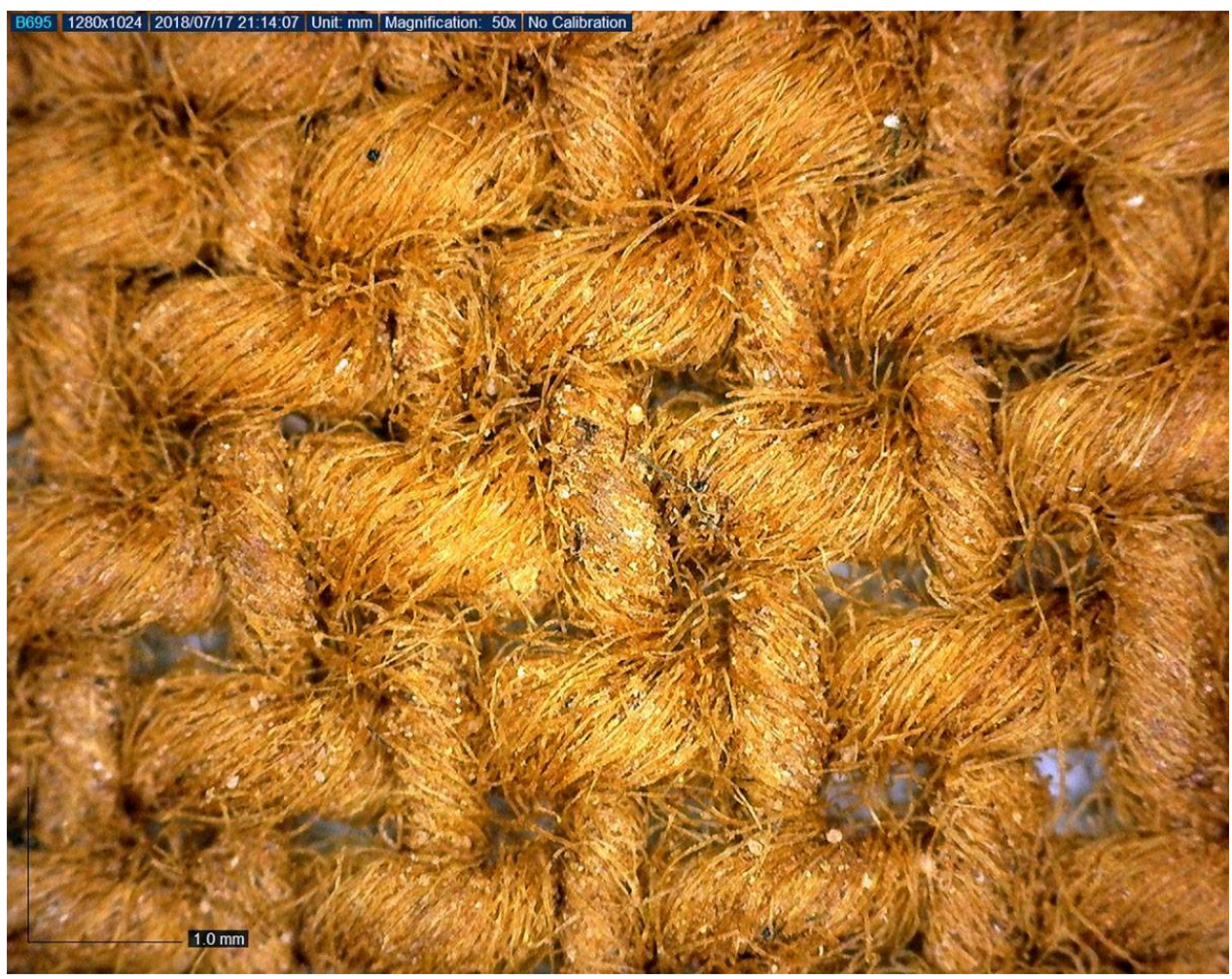

Courtesy of Penn Museum, image E7517.N, photo E. Yvanez 
Figure 12: Starting border and selvedge on cotton textiles from Karanog, magnification $x 30$ and $x 20$ (๔) DinoLite hand-held microscope)

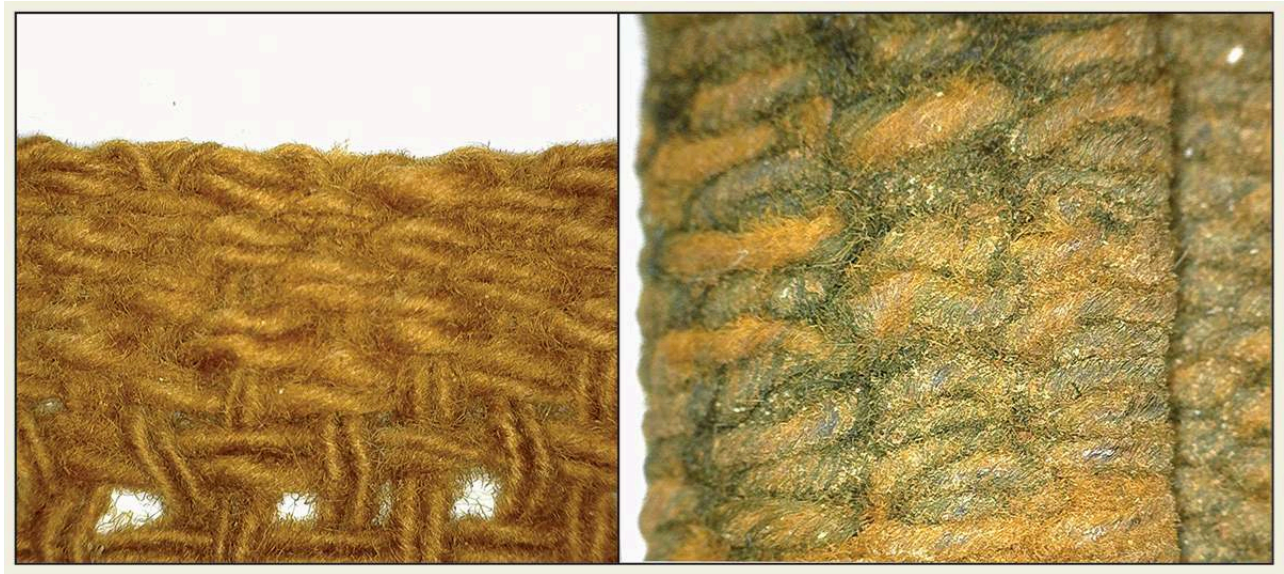

Courtesy of Penn Museum, image E7511.W (left) and E7511.J (right), photos E. Yvanez

This basic weaving technique was chosen for the manufacture of large rectangular pieces, used as multi-function garments. Wrapped around the hips it could have become a skirt or a long dress, while draped over the shoulders it could have been worn as a mantle. As such, the garment used the entire piece of textile as it was woven on the loom, without any tailoring. Hundreds of scattered fragments give us a good idea of the general aspect of these textiles.

Portions of preserved borders and selvedges often exhibit reinforcements (Figure 12): cabled or braided starting borders were used to help support the added tension of both the fabric and the loom weights, while the selvedges were reinforced with the insertion of (generally three) selvedge cords ${ }^{24}$. Many of these features are common in other textile corpora from Antiquity, such as the middle-eastern woollen and linen textiles found in the Judean desert or in Palmyra (i.e. Crowfoot 1955, 1961, Pfister 1937, Yadin 1963). Separated by thousands of kilometres and belonging to completely different cultural spheres, these two bodies of material nonetheless share technical characteristics which seem inherited from their common weaving instrument: the warp-weighted loom (Bergman 1975: 27-39).

However, the Meroitic textiles are immediately recognisable by their specific decorative style. The top and the bottom parts of the pieces could be decorated with single or multiple weft stripes, made with coloured wefts in a tapestry technique. More elaborate tapestry bands could decorate the bottom of the textile, here showing a frieze of meanders and rectangular boxes containing a trio of ankh crosses (Figure 13). A thin braid would maintain the warp threads in place at the end of the weave, which could be finished by a portion of openwork and/or a dense row of tasselled fringes or tassels (Yvanez 2018a: fig. 5 and 8). 
Figure 13: Embroidered flower in blue cotton threads, on a cotton garment from Karanog

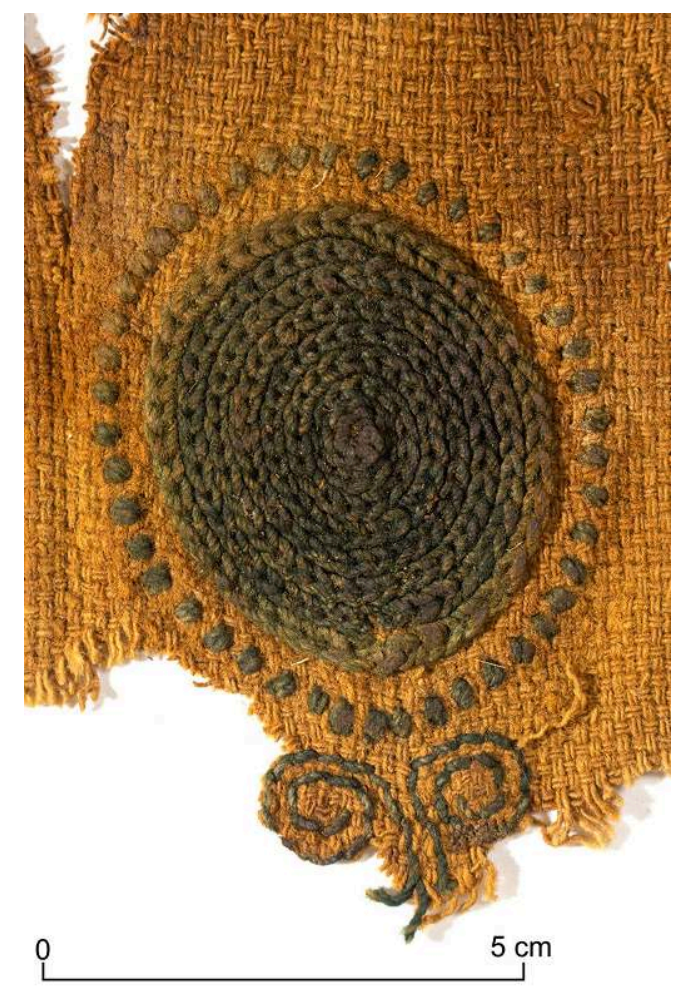

Courtesy of Penn Museum, image E7511.Y, photo E. Yvanez

30 Meroitic cotton clothing is magnificently personified by another kind of garment: the so-called "2-parts costume" worn by the male members of the administrative and religious elite of the kingdom (Adams 2015, Yvanez 2018a-b). It is composed of a large loincloth, worn around the buttocks and covering the thighs, and a pendant apron attached at the front under the navel and going down to the shins. These 2 pieces, sometimes completed by a cape, were both decorated with blue embroideries in stem stitches, sometimes accentuated with red accents, and large circular flowers made with concentric circles in chain stitches (Figure 14). The loincloth and the cape could be shaped with piped hems outlined with blue cords. Represented all over the kingdom through iconography as the garment of choice for the male nobles engaged in diverse processions, such items were only found as preserved pieces in Lower Nubia: at Qasr Ibrim (Adams 1989, 2001: 392, Wild 2011: 115-117), Gebel Adda (Yvanez 2018b: 110-114), and Karanog. 
Figure 14: Tapestry band from Karanog, showing a frieze a meanders and rectangular boxes filled with ankh crosses, made of light, dark blue, and natural cotton threads

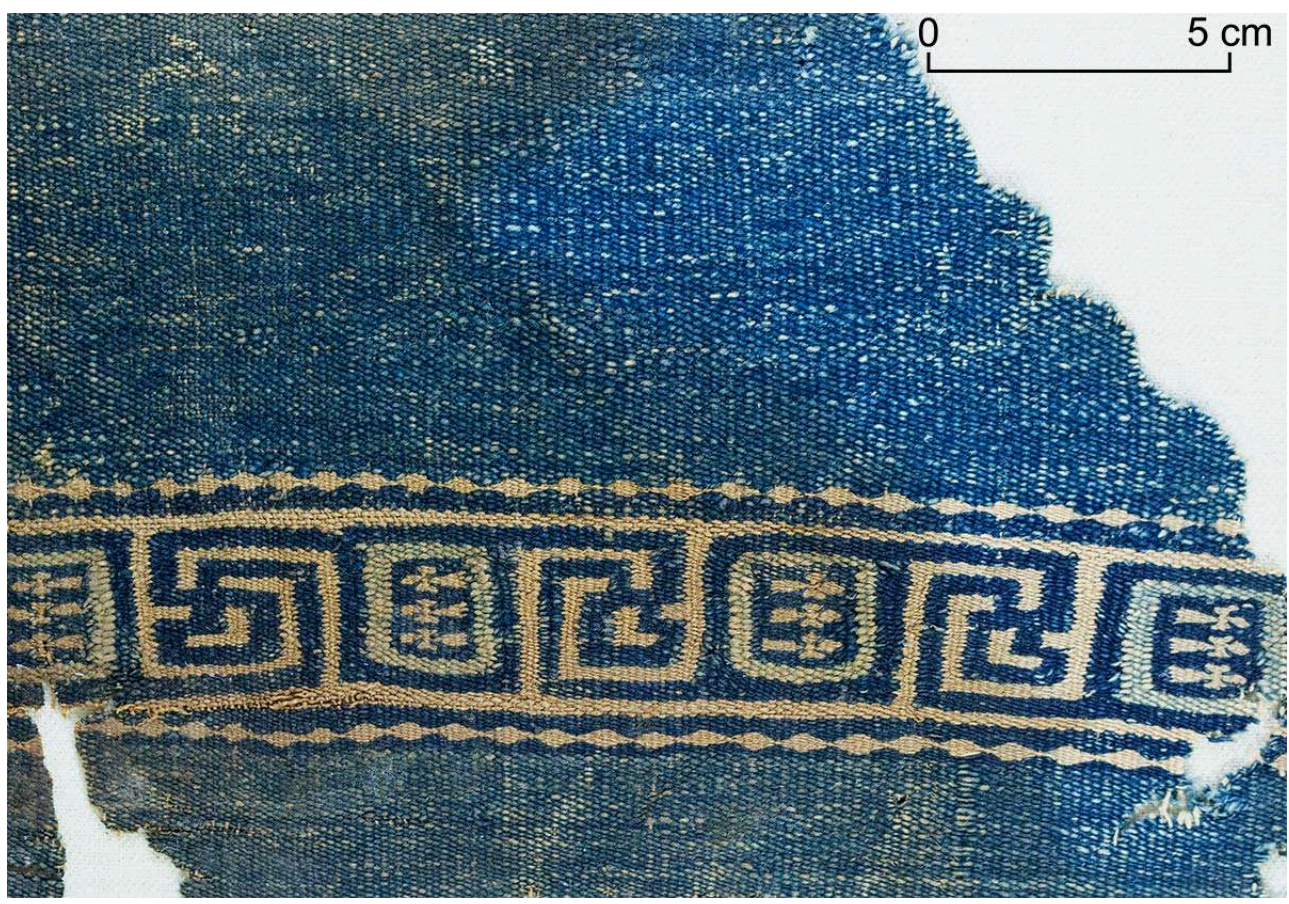

Courtesy of Penn Museum, image E7511.C.2, photo E. Yvanez

31 Cotton also characterises the production of soft furnishings, namely thick blankets in looped pile weave used for warmth and comfort, notably as bedding. Such blankets are often found in graves, laid on a funerary bed of simply spread on the chamber's floor to receive the body of the deceased. This type of textile is regularly found in Nubia, but is also known further south. In Meroe for example, in grave W308, several of them have been used to cover the offerings in a last layer of liturgical protection after the completion of funerary rituals (Yvanez 2016b).

32 Another kind of soft furnishing was exclusively found at Qasr Ibrim and is composed of decorated tapestries used in a religious context. Installed on furniture such as altars or hung on walls, these lavishly decorated textiles would have had a major visual impact in the temples. An exceptional group has been found in the small Isis temple and is dated to the very end of the Meroitic period (e. g. Adams 1987, 2006). Among textiles of utilitarian and votive use, Nettie K. Adams noted the presence of five cotton textiles showing decorated areas in light and dark blue tapestry, with religious patterns linked to the Isiac cult, such as libation ladles, 8-pointed stars, sa-knots, and ankh crosses (eg. Adams 2006: 203, fig. 3). With an average of 40-50 threads per $\mathrm{cm}^{2}$ in the tapestry portions, the hangings (?) are of exceptional quality and several repairs bear evidence to their value and prolonged use. Kept in the British Museum, another fabric fragment shows a frieze of ram-headed deities seated on a chair and holding a staff, over registers of chevrons and check patterns (Figure 15) ${ }^{25}$. This piece shows the use of various techniques, deployed on a half-balanced tabby weave ground: the warp is made of pairs of linen threads (-S), while the weft is formed by plied cotton threads (S2Z) of blue and natural beige colour. The blue figures are made in split tapestry, completed with an embroidered staff, while the geometric register is made with rows of interlaced wefts. Both its subject and its technique - mixing linen and cotton, tapestry, 
embroidery, and interlacing (twining) - make this piece an iconic and unique specimen of the Meroitic weaving arts.

Figure 15: Tapestry fragment from Qasr Ibrim showing a frieze of deities, made of a linen warp and a cotton weft. British Museum EA71854

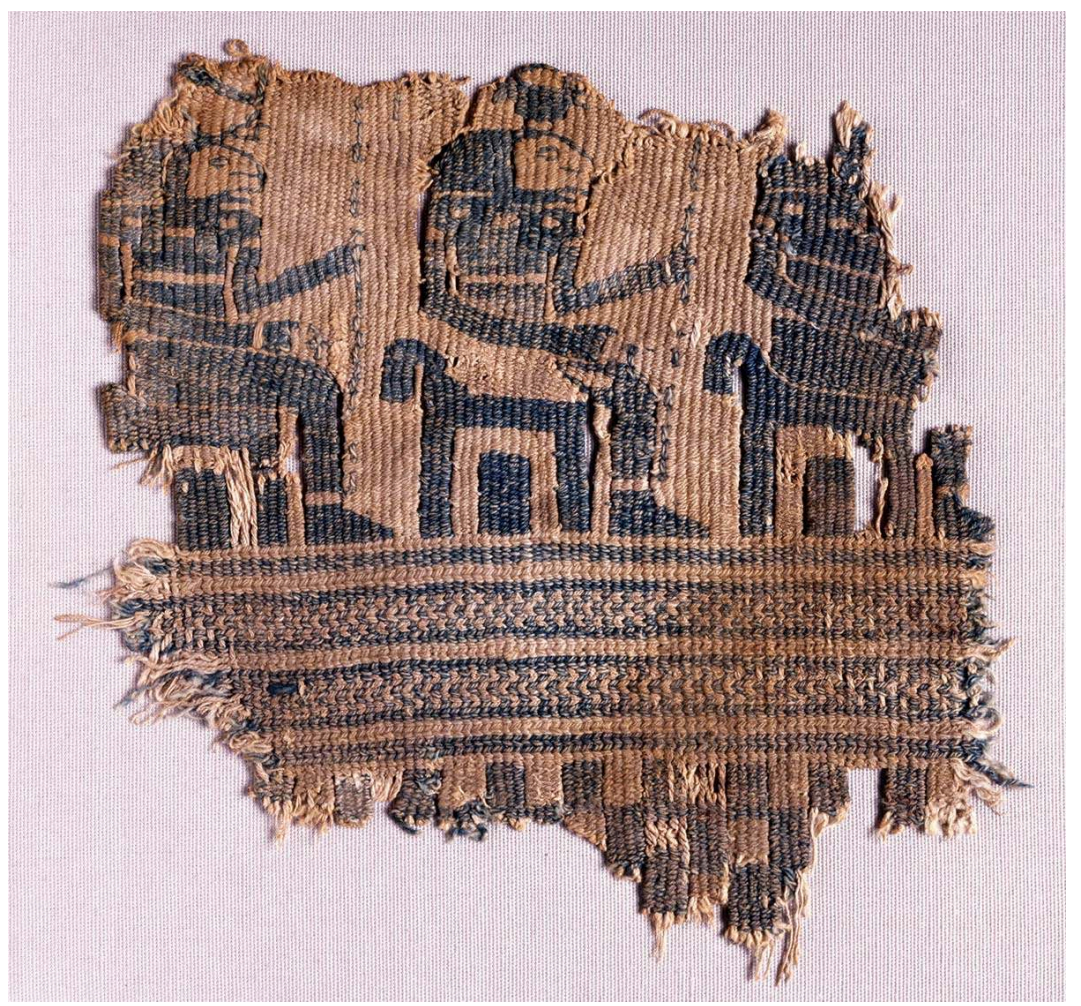

Photo (C)Trustees of the British Museum

Both pile weave blankets and fine tapestry textiles necessitate a large quantity of spun cotton threads and long and laborious weaving. Cotton soft furnishings were therefore highly prized items, both in terms of raw material and processing added value. It isn't surprising to find them treasured in temples and deposited in the last dwellings of high officials and their family.

\section{Who was using cotton?}

Looking at the cotton textile production as a whole, a distinctive style fast emerges. It can be schematically defined by the presence of recurring technical and visual traits: the use of blue patterns, the common occurrence of tapestry (stripes, motives of Pharaonic, Kushite, and Hellenistic influences), the openwork borders, and a developed taste for tassels and fringes.

This style evolved during the very Late and Post Meroitic periods, to accept decorative and technical influences from Egypt and from the Mediterranean costume (Yvanez 2018b). We notably observe the arrival of the Mediterranean tunic, with clavi and gamma figures in tapestry, which provided the Nubian weavers a new model to experiment with. Indeed, several textiles from Lower Nubia exhibit of mixture of Hellenistic forms adapted to Meroitic know-hows and taste. Wool tapestry portions began to be added to otherwise plain cotton cloths, while Hellenistic gamma figures and 
clavi were reinterpreted in blue cotton filled with smaller Kushite patterns (Adams \& Crowfoot 2001: fig.4.3-4.4, Adams \& Adams 2013: 109-110).

The creation of such a distinctive and homogenous style doesn't seem to be the result of a standardisation of cloth production. Despite its overwhelming representation in the textile and costume archaeological record, cotton clothing and furnishings most probably remained a production "de niche", intended for a very restricted number of people (Yvanez 2018a).

Firstly, it is important to keep in mind that textile clothing in general wasn't a common good in ancient Sudan. Ancient sources such as Roman texts and Meroitic pottery paintings depict on several occasions people going naked or partly naked, wearing only belts or beaded girdles ${ }^{26}$. It is particularly true for shepherds and children, as well as for prisoners from surrounding populations, shown in belts or small loincloths. The great majority of people living along the Nile and engaged in farming and pastoral activities would have also relied heavily on animal products, especially leather, to produce the clothing items required in their daily life activities. Thin fragments of leather, or reddish bone coloration, were observed on the pelvis of many skeletons excavated in Meroitic cemeteries. They attest the wide use of leather clothing and corroborate aspects of Agatharchides' comments. Secondly, it is possible that the different ethnic groups which composed the Meroitic kingdom followed different dress traditions, based on other conceptions of self and group identity. Such contrasts would have created different body practices and potentially negate the need for covering pieces of clothing.

On the opposite side of the clothing spectrum, the elaborate and codified Meroitic cotton textiles appear to be the exclusive appendage of the royalty and nobility, developed with the support of the royal authority to manifest the close link uniting the elite families to the central power. As of today, cotton hasn't been found in correlation with non-elite sites or population groups ${ }^{27}$, Qasr Ibrim representing a very northern and unique exception with its thousands of cotton fragments strewed through diverse archaeological contexts. Everywhere else, cotton garments are found inside elite burials. Specific costumes placed in graves and represented on official monuments, such as the 2-parts male costume, even became a type of uniform ${ }^{28}$ for certain civil and military administrators (Yvanez 2018b: 110-114). As such, cotton garments were used as extremely powerful means of non-verbal communication within the different spheres of the Meroitic society.

\section{What were the commanding principles of cotton production?}

39 The study of textiles and tools in conjunction with their context of discovery can help us assess the tenets of cotton production, its output and its organisation. A summary of the information reviewed above indicates the following:

40 - The important number of spinning tools show that textile-related activities occupied a significant amount of time in the daily activities of people living in Meroitic settlements.

- Textile and cotton manufacture are particularly well represented in the regions of Qasr Ibrim and Meroe, two of the main political centres of Meroitic authority.

- Cotton textiles seem intended for a restricted part of the population ${ }^{29}$. 
41 We also know that cotton could be stored: the Ezana inscription, dedicated c. 350 CE by the Axumite king who raided the heartland of the Meroitic kingdom, tells us that his armies "burned their settlements [...] and that his people [...] destroyed the figures of their gods and their provisions of grain and cotton, and cast them in the Seda-river" (translated in Griffith \& Crowfoot 1934: 7) ${ }^{30}$.

These different elements tend to indicate a certain degree of production control: cotton appears to be a valuable crop, linked to the elites and the royal power, and its production could have been partially centralised in key-regions and/or settlements, where it could have been stored and processed.

It is important to note that, to this date, no textile workshop was ever attested in Meroitic Sudan and Nubia. Numerous tools were found in situ, but this fact alone isn't sufficient to attest a true workshop. Defined by the full-time engagement of professional workers responding to a great product demand, a workshop feeds a developed industry and answers to market forces (Andersson Strand 2017). In Sudan, traces of ancient textile production are generally found within multi-purpose industrial areas and seem to involve non-specialised to semi-specialised workers. It was for example the case in Meroe-city, where the bulk of the spinning and weaving tools was found in the domestic and industrial North Mount area. A group of c. 30 spindle whorls was thus unearthed in area M79, a large open-air space in front of buildings II.A and II.B, where other crafts were also practiced, such as faience manufacture and small metallurgy (Yvanez forthcoming). A highly portative activity, spinning was most often carried out in such multifunctional public spaces. Similarly, a very large concentration of loom weights was never found in one single building structure. The only exception is a house located on the Nubian island of Tila, which gave more than 300 weights $^{31}$. However, the building wasn't only dedicated to textile production and housed the many other activities commonly attested on ancient Nubian domestic compounds. In either situation, we aren't in presence of a large dedicated production system able to produce an important output of woven fabrics, like we know from the kingdom of Midas in Phrygian Anatolia for example (Burke 2007). Therefore, textile manufacture, a fortiori in cotton, must have had a limited production output. It nonetheless appears to be of high quality, with regular fabrics made of soft fibers and decorated in a codified style unique to the Meroitic territory and well-attested over its different provinces.

This type of small but high-quality production would imply the involvement of the authorities at some point in the manufacturing process. The Meroitic power would have had an important role to play in cotton cultivation: to recruit the necessary workforce, sometimes in remote regions of the kingdom, to implement a good irrigation system, and possibly to organise a new agricultural calendar able to sustain non-alimentary crops. Royal structures such as palaces and selected settlements could also have been used as a network of storage locations for cotton fibres, where an administrative control could have been applied. The homogeneity of the textiles also points to a partial control of the textile chaîne opératoire, maybe during or directly after weaving (?), allowing the emergence of a dynamic process of craft transmission covering both know-hows and aesthetics. It is possible that parts of this production then entered redistribution channels similar to the diplomatic gift-giving of luxury items which cemented the relationship between local elites and the distant royalty.

Many of these observations remain highly speculative. They are the results of wellinformed and long-forming intuitions, grown from a decade of contact with the 
material and reflecting on its place within Meroitic history. As such, they only represent the current thoughts and state of the research on cotton production in Meroitic Sudan.

\section{Medieval period}

The history of medieval Nubia starts as early as the middle of the $6^{\text {th }}$ century CE, with the arrival of two concurrent missions sent by Byzantium to spread Christianity in the pagan kingdoms along the Middle Nile Valley. The epigraphic sources from that period report the existence of three realms: Nobadia, Makuria and Alwa, this last and southernmost state being the least documented.

In 651/652 a great battle took place at Dongola, the capital city of Makuria, where Nobadian and Makurite armies stopped the Egyptian invader, halting the expansion of Islam. The battle ended by an agreement called baqt, which granted the free circulation of travellers and traders and stipulated the annual obligations of both contractees: the delivery of slaves by the Nubians in exchange for cereals, wine, horses and textiles from Egypt (Maqrizi in Vantini 1975: 642)32. But most of all, the treaty ensured the independence of the Christian kingdoms.

At some time between the end of the $7^{\text {th }}$ century and the beginning of the $8^{\text {th }}$ century $\mathrm{CE}$, the two northern kingdoms, Nobadia and Makuria, merged into one great entity. Its power lasted for the next five centuries. In this new configuration, the former Nobadian state was administrated by a high official called "Eparch" who was responsible for the annual delivery of the baqt. The region between the First and the Second Cataract was the only area within the Makurite kingdom where trade was permitted - no merchant was allowed to go further south without the Eparch's authorisation (Maqrizi in Vantini 1975: 602-603).

Between the $13^{\text {th }}$ and the $15^{\text {th }}$ centuries, incessant dynastic quarrels prompted several rulers to ask for Egyptian arbitration. The frequent interventionism of the Egyptian authorities, as well as the multiple incursions of Arab nomadic tribes, led to the progressive dismantling of the kingdom of Makuria into smaller principalities and local chefferies.

50 The history of the Nubian Christian kingdoms, visually revealed by the magnificent paintings decorating the walls of the Faras cathedral, is mainly reconstructed on the basis of written external sources. Through the prism of these scarce documents, our perception of the Makurite economy is necessarily biased. Considering the baqt treaty as the most informative document about Nubian-Egyptian relations, it would be tempting to reduce Nubia to a sole provider of slaves. However, the analysis of other sources at our disposal shows the diversity of the local economic landscape, where the permanence of cotton cultivation played an important role.

\section{Sources}

\section{Archaeobotanical remains}

51 Archaeobotanical studies on medieval Sudanese sites are still very poorly developed. Except for the Qasr Ibrim fortress (see Figure 3), where cotton is attested from Antiquity to Ottoman period (e.g. Clapham \& Rowley-Conwy 2009, see above), cotton 
was identified in Nauri, a medieval site located few kilometres north of the Third Cataract (Fuller \& Edwards 2001) ${ }^{33}$. The remains are essentially desiccated fragmented seeds with attached fibres, which may attest the crop's cultivation in the vicinity and its processing for textile production on site. Cotton appeared in small quantities in two samples from a set of four, collected from two locations in the settlement. It is difficult to estimate the amount of cotton produced in the area, but its presence among the local crops at Nauri (such as barley, sorghum, millets, cowpea, lentil, etc.) remains a valuable piece of information. It shows the permanence of traditional crops within the longterm agricultural exploitation of Nubia and highlights cotton craft as a well-integrated component of local culture and everyday life.

\section{Textiles}

As mentioned earlier, the majority of textiles discovered in Sudan come from sites located in Nubia, which reflects both the historiography of archaeological research and environmental conditions. It must be noticed that cotton does not appear systematically in the textile assemblages from the medieval period, where wool is the dominant fibre. However, caution should be exercised in the interpretation of the absence of cotton for we must keep in mind that cotton is mostly composed of cellulose, an ideal food source for micro-organisms (Timar-Balazsy \& Eastop 1998, Levin \& Pearce 1998), and therefore offers attractive conditions for the colonisation of fungi and bacteria in turn responsible for fibre degradation ${ }^{34}$. Its hygroscopic nature also led to differential conservation depending on the varying presence of water: on the island of Kulubnarti for example, cotton mostly disappeared from the cemeteries after several episodes of flooding and water infiltrations, while it remained well preserved in the town, located further up from the river course (see below).

The textile data provided by the Qasr Ibrim material is by far the most numerous and cannot be compared on an equal footing with data from any other site, nor by its quantity, nor on the long-term chronology. The study of this incredible number of fabrics ${ }^{35}$ allowed Nettie K. Adams to reconstruct the fibre frequency variations in Qasr Ibrim from $200 \mathrm{BCE}$ to $1500 \mathrm{CE}$ (Adams 2010: 164, fig. 39). Her publication of the textiles from the medieval period reveals a strong decline of cotton fabrics between the $7^{\text {th }}$ and the $9^{\text {th }}$ centuries, while at the same time wool reaches $70 \%$ of the textile assemblage. In the $12^{\text {th }}$ century, the fibre frequency is more balanced, with cotton and wool each representing c. $40 \%$ of the textile material, while flax makes up to $20 \%$. Between the $14^{\text {th }}$ century and the $16^{\text {th }}$ century, wool and flax progressively decline allowing cotton to grow to $70 \%$ of the whole textile landscape. The study of thousands of fabrics led Nettie Adams and Elisabeth Crowfoot to the identification of more than 50 different fabric types, which once again remains quite exceptional in the textile corpus of the medieval period. The climatic conditions of the site also allowed the preservation of the textiles to such a point that many garments could be reconstructed. The global tendency established by Nettie Adams at Qasr Ibrim seems pertinent for other Nubian sites with preserved cotton textiles (Figure 16). 
Figure 16: Histogram tracking fibre frequency on several medieval sites

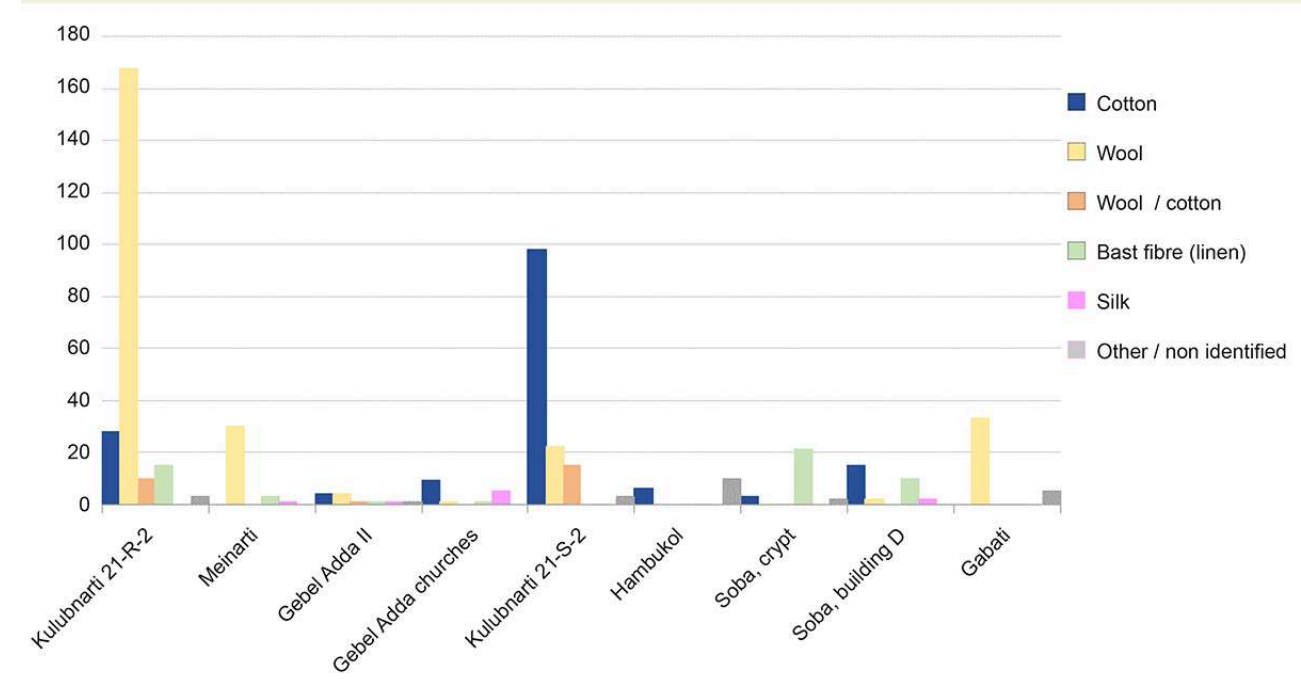

Graph M. Wozniak/E. Yvanez

Supplementary data to the histogram

\begin{tabular}{|l|c|c|c|c|c|c|}
\hline \multicolumn{1}{|c|}{ Sites } & Cotton & Wool & C/W & Bast fibre & Silk & Other \\
\hline Gebel Adda II $(550-850$ CE) & 4 & 4 & 1 & 1 & 1 & 1 \\
\hline Soba East $(650-900$ CE) & 3 & 0 & 0 & 21 & 0 & 2 \\
\hline Kulubnarti, cemeteries $(600-900$ CE) & 28 & 168 & 10 & 15 & 0 & 3 \\
\hline Soba East, storage building $(800-1300$ CE) & 15 & 2 & 0 & 10 & 2 & 0 \\
\hline Gabati $(900-1200$ CE) & 0 & 33 & 0 & 0 & 0 & 5 \\
\hline Hambukol $(1000-1300$ CE) & 6 & 0 & 0 & 0 & 0 & 10 \\
\hline Meinarti $(1200-1300$ CE) & 0 & 30 & 0 & 3 & 1 & 0 \\
\hline Gebel Adda, churches $(1200-1400$ CE) & 9 & 1 & 0 & 1 & 5 & 0 \\
\hline Kulubnarti, settlements $(1200-1500$ CE) & 98 & 22 & 15 & 0 & 0 & 3 \\
\hline
\end{tabular}

*The percentages indicated for Qasr Ibrim were copied from Nettie K. Adams's graph (Adams 2007: fig. 33.2, 203). Numerical values do not appear in the article.

In Kulubnarti for example, cemetery $21-\mathrm{R}-2$ (dated from the $7^{\text {th }}$ to the $9^{\text {th }}$ centuries), reveals a very high percentage (c. 77\%) of woollen textiles while cotton represents less than $15 \%$ of the fabrics. A much later occupation on site 21-S-2, also on Kulubnarti island and dated to the Late Christian and Post-Christian periods $\left(13^{\text {th }}-17^{\text {th }}\right.$ centuries $\mathrm{CE})$, shows an assemblage largely dominated this time by cotton textiles (71\%). Once again, it corroborates the data from the end of the medieval period at Qasr Ibrim. The same observations, on a much smaller scale, can be noted at Gebel Adda: the few graves excavated in the Christian Cemetery II reveal similar proportions for cotton and wool, while late burials from Churches VI and VII, respectively dated to $13^{\text {th }}-14^{\text {th }}$ centuries and $14^{\text {th }}-15^{\text {th }}$ centuries, contained a majority of cotton textiles. In this "Nubian set", Meinarti appears as an exception, for not one cotton textile has been found on the site $^{36}$. This absence could be related to the Egyptian invasion of $1286 \mathrm{CE}$ and the sack of the town, during which cotton might have been taken by the Egyptian army, as it happened in Ibrim (Adams 2002: 93-95).

In Central Sudan, from the dozen Makurite sites where textiles have been found ${ }^{37}$, cotton only appeared on two sites: near Dongola, in Hambukol (Vogelsang-Eastwood 2001), and in Soba (Welsby 1998: 177-182; Welsby \& Daniels 1991: 300-309). In Hambukol, preliminary test excavations unearthed a total of 33 textiles in building A-1, 
dated from the $11^{\text {th }}$ to the $13^{\text {th }}$ centuries (Anderson 2004, Vogelsang-Eastwood 2001). The 16 published fabrics were divided by fibre type, either cotton or camel (dromedary) hair. At Soba, three cotton textiles were identified in the crypt of the northern church dated to mid- $7^{\text {th }}-9^{\text {th }}$ centuries, while the majority of fabrics consisted in linens. On the same site, cotton was also found in storage building $D$ dated to $9^{\text {th }}-13^{\text {th }}$ centuries. There, cotton and linen fabrics formed the majority of the textile findings alongside few fragments of wool and silk. Because of the low amount of fabrics and their peculiar contexts, it seems too early to compare the data from Central Sudanese sites with the general pattern established for the Nubian region.

\section{Tools}

57 The medieval textile savoir-faire is attested by numerous tools used not only to process raw fibres into threads, but also to weave those threads into fabrics. Depending on their final destination, the textiles were tailored and sewn into garments or furnishings and embellished with decorative patterns. The categories established for the Meroitic and Postmeroitic periods also work for the medieval period, for the stages of the chaine opératoire remain unchanged:

- Spinning tools: spindles and spindle whorls.

- Weaving tools: bone picks ("weaving picks"), shuttles, weaving combs, thread beaters. Loom weights are almost absent in the assemblages examined so far. During the medieval period the fixed heddle loom (2-beam vertical loom?) probably replaced the warp-weighted loom ${ }^{38}$.

- Sewing tools: needles.

Spindles whorls are by far the most numerous objects among the textile implements (Figure 17). Interestingly, the medieval spindle whorls from Qasr Ibrim are still made of turned wood ${ }^{39}$, while on other Nubian sites as well as in Central Sudan they are all made from reused potsherds.

Figure 17: Spindle-whorls from Melik el-Nasir

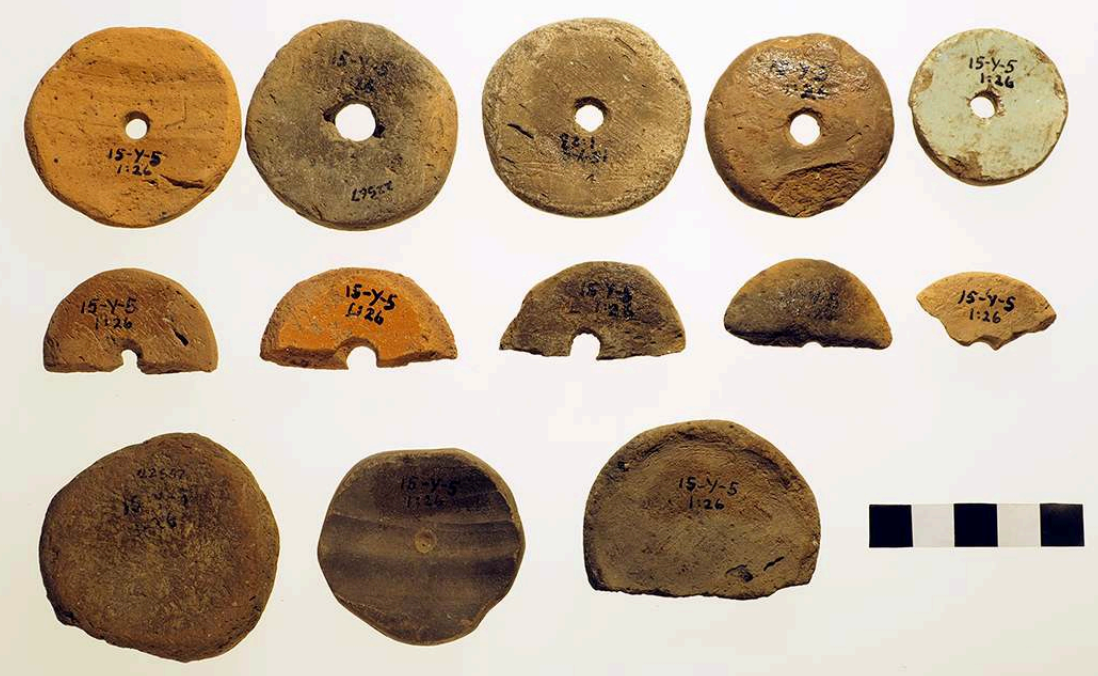

Photo M. Wozniak, courtesy of the Sudan National Museum 


\section{Iconography}

In the present state of our knowledge, it appears that Sudanese medieval iconography focussed on religious themes and was mainly used by rulers to legitimize their power. Kings, queens, and Church dignitaries were often represented under the protection of Christ or the Virgin Mary on the walls of cathedrals and churches. Lavishly decorated garments, most probably tailored from imported silks, are characteristic of these portraits. Some costume pieces, such as long white robes (Figure 18a, see also Figure 23) or large trousers worn under richly ornamented mantles, may have been made of cotton, but of course, the sole colour of a painted textile cannot be considered a valid criterion for fibre identification.

The corpus of medieval paintings from Nubia contains several private ex-votos where the donor of the painting (mostly clergy members and pious women) is usually figured barefoot (Figure 18b). As for the representation of "common" people, they appear so far in an exceptional composition found in Old Dongola as musicians and dancers in a kind of festival related to the Virgin Mary (Martens-Czarnecka 2005). However, they wear masks and outfits which seem specifically related to the festival performance. Inhabitants of medieval Sudan might also be identified sometimes in Nativity scenes (as shepherds), where there wear loincloth and long sashes passed and knotted around their torsos (Figure 18c).

Figure 18a: Portrait of bishop Kyros, Faras Cathedral, second half of the $9^{\text {th }}$ c., SNM inv. KH 24349

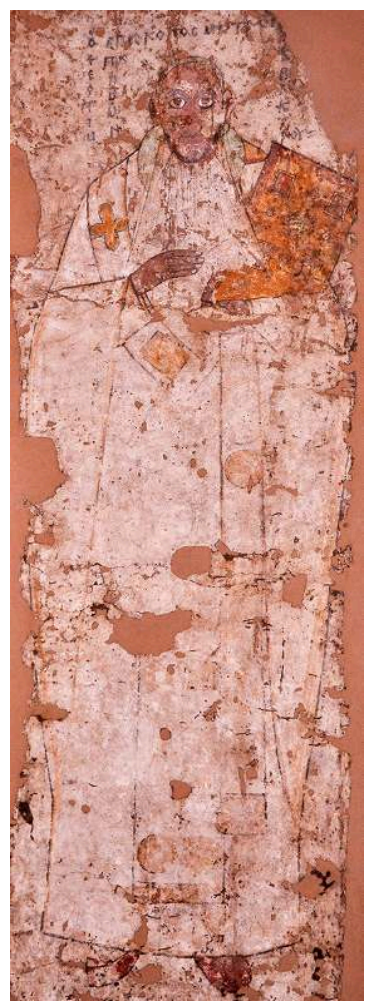

Photo M. Wozniak, courtesy of the Sudan National Museum 
Figure 18b: Ex-voto of eparch Marikouda, Abd el-Gadir church, mid 13 ${ }^{\text {th }}$ C., SNM inv. KH 24325

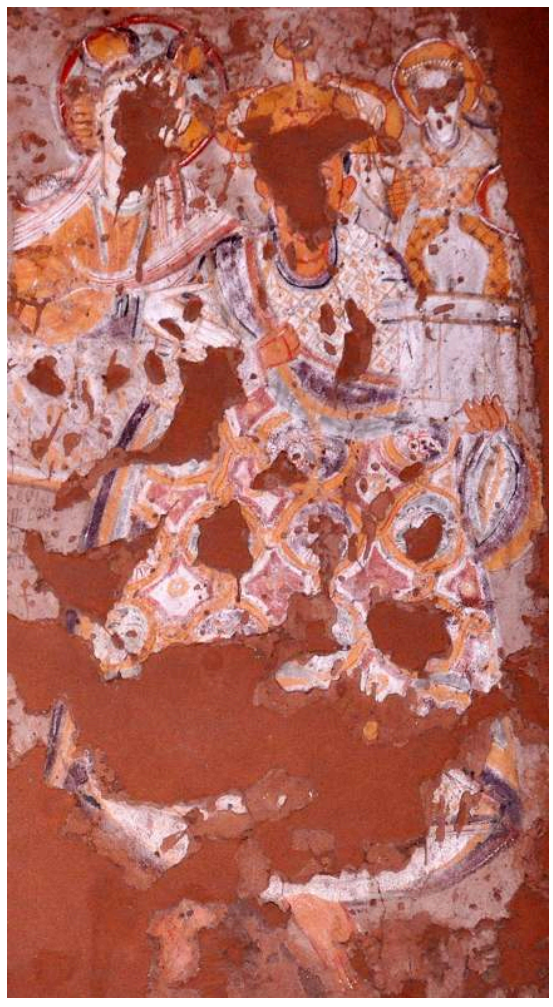

Photo M. Wozniak, courtesy of the Sudan National Museum

Figure 18c: Shepherds in the Nativity scene from Faras Cathederal, $10^{\text {th }}$ c., SNM inv. KH 24365

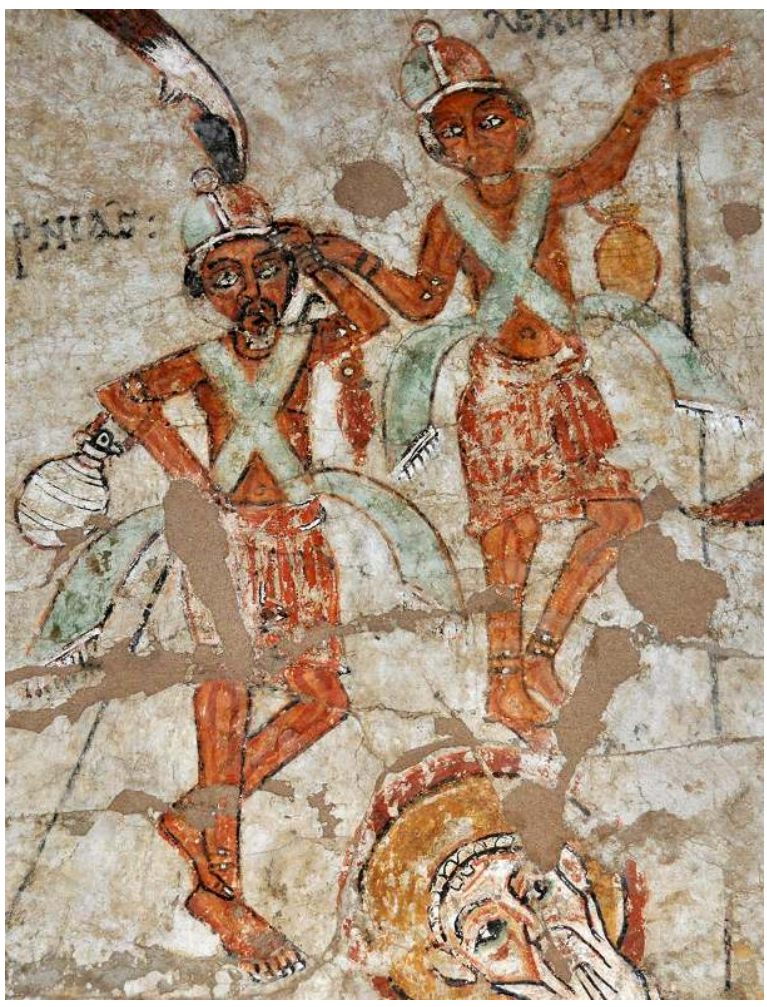

Photo M. Wozniak, courtesy of the Sudan National Museum 


\section{Textual sources}

addressed by private merchants to the Eparch of Nobadia. Their publication hasn't been completed yet, but W.Y. Adams unveiled their content by editing a preliminary translation of several of them (Adams 2010: 246-255). The correspondence provides many fascinating avenues for research about politics and trade organisation in Makuria and in Alwa, as well as a growing body of evidence about imported items related to textile consumption and production during the medieval period. However, the positive identification of cotton cloths within this list will have to wait the complete edition of the texts.

Last but not least as a source for our study is a small group of Arabic and old Nubian written sources, which span four different categories: historical, economic, epistolary, and literary. Despite their scarcity, they cover various periods and distinct aspects of cotton economy.

compilations created by Egyptian geographers and historians. Cotton is quoted as a cultivated crop in Arabic geographical texts - mostly al-Uswani cited by later authors such as al-Maqrizi. It also appears in texts relating the Egyptian invasions in Nubia during the $12^{\text {th }}-13^{\text {th }}$ centuries, where it is described as the object of taxation (Maqrizi in Vantini 1975: 609, Troupeau 1954: 276-279, Kheir 1985):

"[...] the two provinces of al-'Ali and al-Jabāl - which accounted for one quarter of Nubia - were to belong to the Sultan because of their proximity to Aswān; all the cotton and dates produced in these two provinces should be handed over [to the Sultan] together with any other rights ( $h u q \bar{u} q)$, which were reserved to the kings his predecessors, according to the tradition." (Ibn al-Furat in Vantini 1975: 533).

Cotton is mentioned in the description of sacks taken after battles by Egyptian troops as a booty item - for example by Abu-Salih describing Saladin's campaign:

"In the town a quantity of cotton (qutn) was found which he [Shams ad-Daulah] carried off to Kūs (Qos) and sold for a large sum." (Vantini 1975: 328).

this time in Old Nubian. Cotton fields are mentioned in land sales documents both as sale objects and as descriptive landscape elements delimiting plots:

"[...] On the south is the land of Anieion-Asti, and on the north is the land of EnonAsti, in the cotton field (?) and in the cultivated depression of the orchard everything is mine; On the south is the land of the Anieion-Asti, and on the north is the land of the Peter-Church, there is 1 plot in the cotton field (?), one third is mine; [...]" (Sale of land, document NI 64.1.30.6. dated from 1 Nov. 1191, after Browne 1991).

The last category of written sources, namely $19^{\text {th }}$ century travellers' descriptions of Sudan, must be used with caution as they are chronologically much later than the former documents. Still, the strong permanence of traditions in Sudanese society allows us to consider these texts as a useful insight into the everyday life of its inhabitants, which have probably not changed so much since the medieval period (Osman 1982). The weaving of cotton cloth is frequently mentioned as a domestic activity, accomplished by women (Burckhardt 1819: 36). 


\section{Historical implications}

68 caution when drawing general considerations about its exploitation and its role in the
economy of the Makurite state. While Nubia still acted as a "corridor to Africa" (Adams
1977), exchanges with its Egyptian neighbours appear to have mainly focused on the
delivery of slaves and exotic animals, and not on any cotton products. However, the
persistence of cotton's presence through the spectrum of various sources demonstrates
its long-term integration within the agricultural, cultural and social practices of
medieval Sudan.

\section{Where was cotton cultivated?}

aeobotanical and textual sources indicate that cotton was cultivated in Lower Nubia and in the Dar Mahas region ${ }^{40}$. Cotton seeds with attached fibres were positively identified in Qasr Ibrim (cf. Fig. 2) as well as in Nauri. This data may confirm the acuity of al-Uswani's observations while travelling in Nubia in the $10^{\text {th }}$ century. His History of the Nubians is partially known to us as cited by later historians such as al-Maqrizi, who mentions the presence of "few cotton plantations" in the district of Saqludha" ${ }^{41}$ AlUswani described the small number of plots and assessed that local cotton was woven into coarse cloth, reinforcing our perception of the medieval textile manufacture as a domestic and local production. Interestingly, a similar observation was made centuries later by L. Burkhardt:

"The Nubians here grow a little cotton, small plantations of which are everywhere met with from Kenne, in Upper Egypt, as far as Dongola" (Burckhardt 1819: 36).

The textual findings from Qasr Ibrim, especially the legal documents dealing with land sales, offer valuable background information to cotton cultivation. Their recent analysis by Giovanni Ruffini (Ruffini 2012: esp. chap. 4) shows the limited size of the parcels (from 6 to 19 square meters per plot), caused by the scarcity of arable land in that area, as well as the multiplication of shared property of individual plots due to the Nubian inheritance system (op. cit.: 82 and note 25). In these documents, cotton appears along with palm-trees, millet, peas, or in garden parcels. Such a diversity of crops on the same small lands reminds us of oasian agriculture, where a mix of crops is cultivated together and several of them dedicated to trade ${ }^{42}$. The attentive reading of these documents sheds light on the existence of richer tenants (administrative or clergy dignitaries, including women), selling or buying numerous plots, as well as the frequent mentions of churches as land owners. It is then reasonable to assume that these rich land owners, be it town notables or religious institutions, may have produced cash crops.

71 The production of a surplus by the inhabitants of Nubia is also supported by the historical writings. Describing Saladin's campaign in Nubia, Abu Salih the Armenian mentions a substantial quantity of cotton found by Shams ad-Daulah's troops in Qasr Ibrim in 1173. Some scholars questioned the identification of cotton in this text, arguing that the Arab word "qtn" initially meant "flax" (Gervers 1990). It should be kept in mind that in the $12^{\text {th }}-13^{\text {th }}$ centuries, Egypt's main textile product is still flax, while cotton is mostly an imported commodity (Serjeant 1948, Lombard 2002: 61). In our opinion, the lucrative value of the booty selling supports the hypothesis that the raw fibre found at Qasr Ibrim was indeed cotton. After the raid, the cotton was transported 
to Qos in Upper Egypt, and "sold for a large sum" (Abu Salih in Vantini 1975: 328). We don't know if this cotton was collected from different properties or from a unique place nor what was its primary destination, but its amount was important enough to be mentioned as one of the main items of their plunder.

The later historian Ibn al-Furat delivered an account of the Egyptian invasions of Nubia at the end of the $13^{\text {th }}$ century, when the Sultan claimed the provinces of al-Ali and alJabal, near Aswan, as his own property. He stated that this territory represented one quarter of Nubia and mentioned the important production of cotton and dates, which should consequently belong to the Sultan (see above).

The documentary potential of textile tools, especially spindle whorls, to track and locate cotton production is lower for medieval times than it is for the Meroitic period. On medieval sites, textile tools were collected to various degrees, during surveys, salvage excavations, and planned excavations. Not always recognised as such, spindle whorls have been unequally published, which prevents us from forming a general opinion of spinning practices in medieval Sudan. Ongoing research by the author (M. Wozniak) has led to the new examination of c. 300 spindle whorls (both complete and fragmentary), allowing us to deliver preliminary observations. With the previously noted exception of Qasr Ibrim, all the medieval spindle whorls are made of reused potsherds, chipped into roundels and perforated in their centre (see Figure 17). Beside the varying thickness of the whorls - more important for the wooden than the ceramic ones (c. 2-3 cm thick for spindle whorls made of wood and c. $1 \mathrm{~cm}$ thick for the potsherds) - the other technical features are quite homogeneous. The most common diameter is between 4 and $5 \mathrm{~cm}$, with a central perforation measuring from 0.6 to $1 \mathrm{~cm}$ of diameter. Their weight ranges from 10 to $20-25$ gr. Such spindle whorls would have been adapted to spinning short fibres (cotton of course, but also fine wool from local livestock, see Crowfoot 1931: 13-14) into thin to medium threads. This quality is well attested in the textiles collected from various medieval sites from Nubia and Sudan.

\section{What was cotton used for?} urban areas, there were mostly torn rags, so their initial function was difficult to ascertain. However several fragments still preserved diagnostic features such as hems or seams, which gave precious indication of the primary nature and use of the textile. The Qasr Ibrim material allowed the reconstruction of some of the garments as well as the identification of some furnishing pieces.

Interestingly, cotton fabrics were often used for tailored clothing, such as hats, long tunics, and trousers. Attested by seams or hems, tailored garments can only be found among the cotton and linen fabrics, and remain very rare until the Late Medieval times (Adams 2010: 165).

The tunics, with their wide flowing sleeves and round head opening (a very clear diagnostic feature), were very similar to the modern galabiyeh worn today by Sudanese men. Among the garments identified as tunics in the archaeological material, the presence of an opening at the front was frequently noticed. The tunics were usually tailored in plain weave fabrics (tabbies), with S-spun or Z-spun yarns (Figures 19a et 19b). 
Figure 19a: Fragment of cotton cloth with S-spun threads from Kulubnarti, BM inv. EA78430

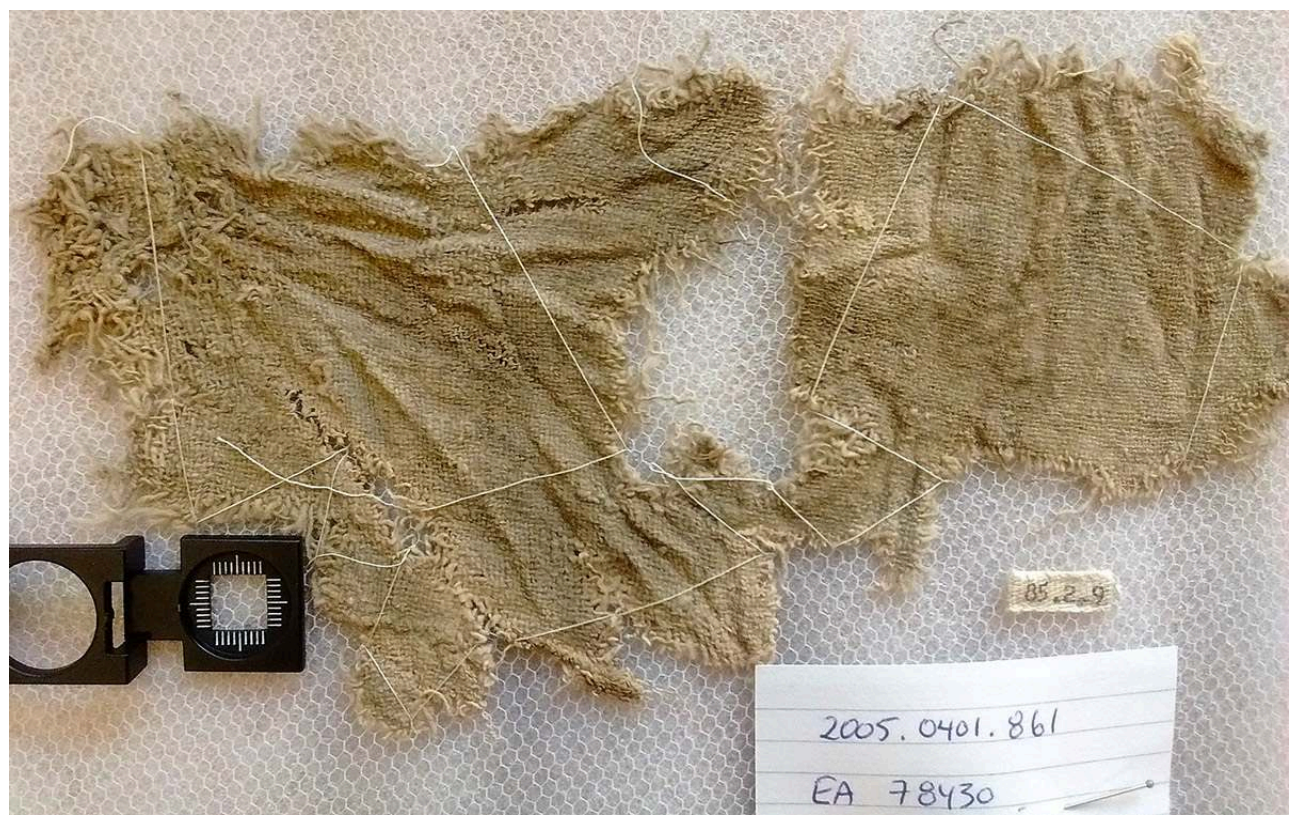

Photo M. Wozniak, courtesy of the British Museum

Figure 19b: Cotton cloth from Kulubnarti under microscope, BM inv. EA78430

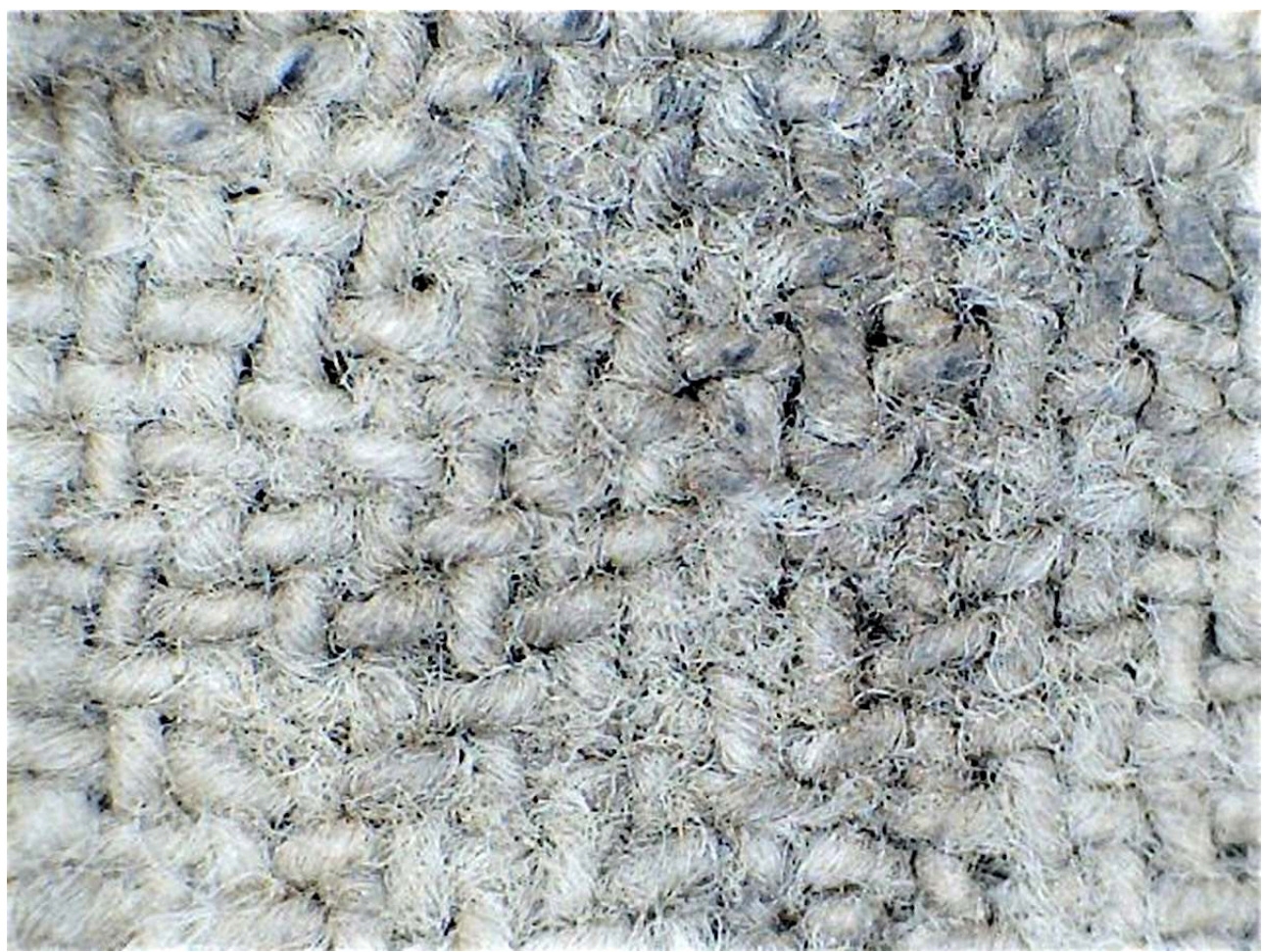

Photo M. Wozniak, courtesy of the British Museum

Closer examination of both cotton and woollen tailored garments demonstrates the permanence of the fibres' spinning direction in -S through most of the medieval textile production in Sudan. S-spun fibres are also typical of Egyptian manufacture, notably visible on the many linens that characterised its biggest textile output (Bouchaud et al., 
this volume). Cotton fabrics were produced in Egypt too, but mainly from threads imported from Syria or India (Lombard 2002: 70-71), where the traditional spinning direction is $-Z$. The tendency to assign an Egyptian origin to the better manufactured fabrics found in Nubia should then be nuanced: the long tradition of cotton tabbies, developed in Sudan since the Meroitic period, and the continuation of S-spinning practices are two valuable criteria to consider a local origin for these S-spun cotton tunics.

Trousers were often made of cotton but also of linen fabrics. The most diagnostic features for the identification of trousers are: the casing for the drawstring, the gusset (or its absence), and remnants of trousers legs (Adams 1996: 172, 2010: 167-168). Similarly to the long tunics, the trousers were made from plain weave tabby fabrics, generally with S-spun yarns and occasionally with Z-spun yarns. Very few occurrences of trousers are known for the Early Christian Period ( $7^{\text {th }}$-mid $9^{\text {th }}$ century CE) at Qasr Ibrim, while the Late Christian Period $\left(12^{\text {th }}-15^{\text {th }}\right.$ century CE) provided many more attestations.

Round caps, formed by triangular textile pieces sewn together, were also found at Qasr Ibrim and in Gebel Adda. Very simple models are tailored from cotton plain weave fabrics (S-spun yarns in Qasr Ibrim, Z-spun yarns in Gebel Adda), while other pieces featured additional ornamentation in silk and even fur.

A special mention should be made about the identification of cotton loincloths (Figure $20)^{43}$, which appear most frequently in small villages around Kulubnarti (Adams 1999: 53 and tables 8 and 9) ${ }^{44}$, but were also identified on the urban site of Qasr Ibrim (Adams 2010: 168) ${ }^{45}$. These trapezoidal pieces, shaped during the weaving process (Bergman 1975: 23-25), attest the permanence of a very old dress tradition going back to the Kushite period. Recently, another Early Medieval specimen was identified on Sai Island, this time woven in wool, possibly from dromedary hair (Yvanez et al. forthcoming). 
Figure 20: Trapezoidal loincloth, drawing by. I. Bergman

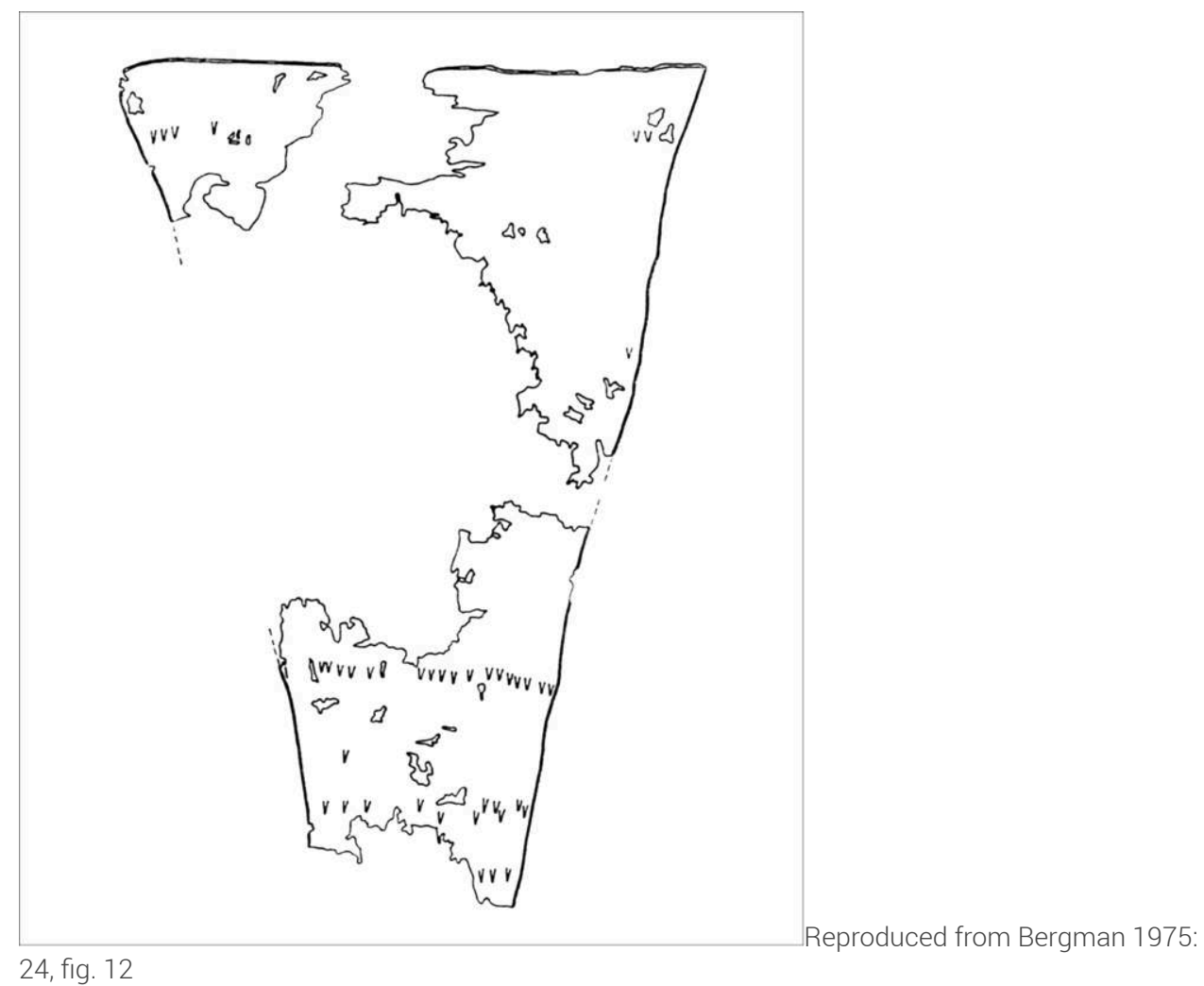

81 Another interesting observation is the presence of very open tabby fabrics ( 3 to 5 threads per $\mathrm{cm}$, leaving sometimes a space of 5 to $7 \mathrm{~mm}$ between two threads), all made of S-spun cotton yarns and most probably used as shrouds (Figures 21a et 21b). They are mentioned in the description of c. 30 graves excavated in Kulubnarti cemeteries and dated to the Early Christian Period, while only one occurrence was identified at Qasr Ibrim for the same period (Adams 1999: 58, and tables 10-11). 
Figure 21 a: Cotton shroud from Kulubnarti, BM inv. EA84553

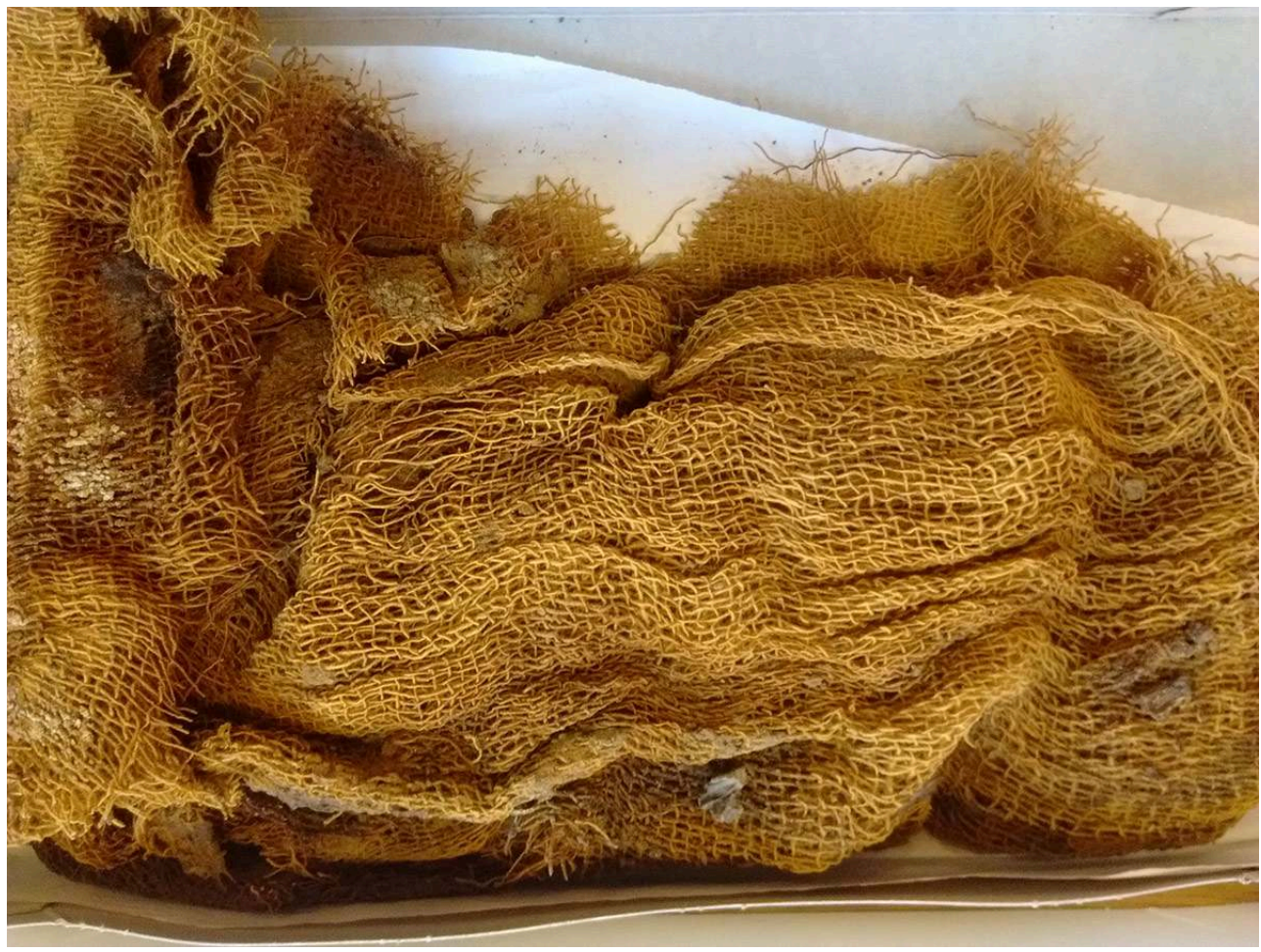

Photo M. Wozniak, courtesy of the British Museum

Figure $21 \mathrm{~b}$ : Detail from Kulubnarti cotton shroud, BM inv. EA84553

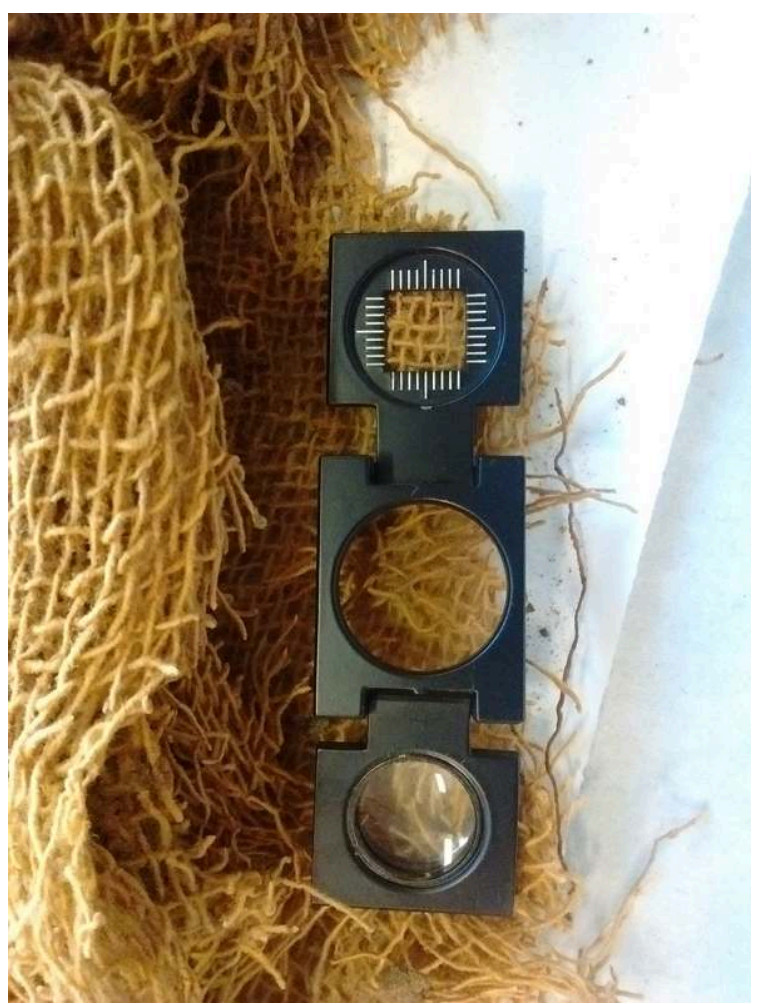

Photo M. Wozniak, courtesy of the British Museum 
Finally, cotton fibres were also used to make a type of textile exclusively found in funerary context: the bindings maintaining the shroud in place around the deceased's body. Cotton threads are assembled in simple strings, braids, and more sophisticated bi-colour tapes (Figure 22), where dark wool contrasts with light coloured flax or cotton threads (Adams 1999: 55). The presence of mixed fibres is also attested in braids.

Figure 22: Bi-color tape from et-Tereif, BM inv. EA77366

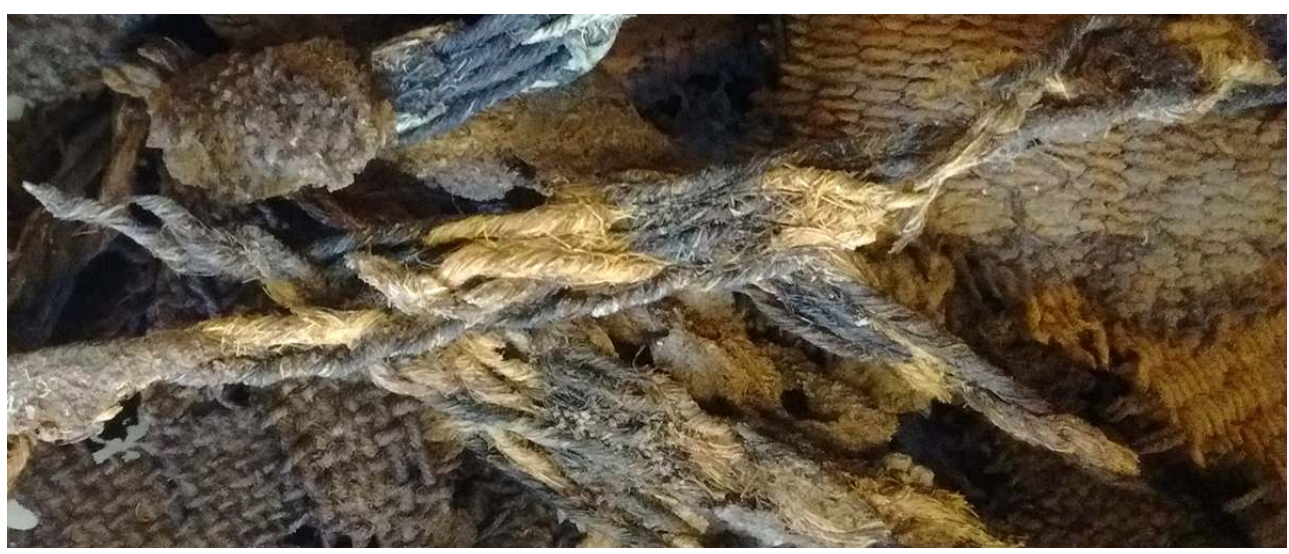

Photo M. Wozniak, courtesy of the British Museum

Furnishing textiles made of cotton are only known in the Qasr Ibrim corpus and dated to the Early Medieval period (mid- $7^{\text {th }}$ century - end of the $12^{\text {th }}$ century CE). Cotton is attested in bedding elements such as cushions or as reused rags employed in the stuffing of crude mattresses. It is also probable that large rectangular textiles made of cotton and wool were frequently employed as blankets as well as clothing items (they are often described in the literature by the words "sheet", "shawl" or "mantle"). The same observations have been made for the Late Medieval period, with the notable addition of quilting. The rare fragments observed at Qasr Ibrim are made of two layers of cotton fabric with cotton wadding in between, maintained in place by quilting stitches in parallel rows every 1 to $3 \mathrm{~cm}$ (Adams 1996: 149).

\section{Who was using cotton?}

Curiously, among the cotton clothing identified in the Qasr Ibrim material, the two most common garments are mainly those traditionally worn by men: they are the tailored long tunics and trousers. We shouldn't however promptly assume that these features were exclusive and characteristic of the male costume in the medieval society, for these garments were probably reserved to a small elite anyway. The inhabitants of the kingdom of Makuria are very scarcely mentioned in the written sources and, when they are, they are generally described in derogatory terms as "naked people". At best, the rare indications of clothing concern loincloths or animal skins. In the iconography, portraits were the privilege of the elite and consequently common people almost never figure in Nubian art. On the other hand, the archaeological record contains a vast number of artefacts related to textiles: the fabrics themselves but also textile implements used for spinning and weaving. The available data reveals contradictory information about the clothing traditions of Christian Nubia. While the textile remains show its inhabitants were dressed in a variety of costumes and mastered the different crafts involved in textile production, the Arab writers repeatedly depict them as naked 
people. We may read these comments as common literary topos about the Sūdān (litt. 'the Blacks') and simply dismiss them. If we do consider these statements as containing valuable information about the Nubian population, it becomes challenging to set these observations in a more comprehensive context: hypotheses would need to be tested, evaluating the Nubian people's (perceived) material paucity and studying the coexistence of communities with different clothing traditions.

Long tunics and trousers were mostly recovered from dignitary graves at Qasr Ibrim (Crowfoot 1977) and Gebel Adda ${ }^{46}$, or more recently in Old Dongola (Godlewski et al. 2012). In Kulubnarti, only four textile fragments belonged to long tunics, most likely used by members of the nobility. As the later multiplication of occurrences show, trousers became a more popular form of garment among the elite during the Late Medieval period.

In smaller settlements such as Kulubnarti, we may assume that the most common garments were loincloths, which appear in growing quantities, and are woven in wool and sometimes cotton (see Figure 20). Another item of clothing is the common woollen rectangular piece, which could have been wrapped over the shoulders as a mantle, or used as a blanket. The importance of leather in clothing practices, of both the population and the dignitaries, should also not be underestimated (Adams 1998: 61-62, 1999: 69-70).

\section{How much cotton was produced?}

This question is very delicate to address. Among available sources, only a couple of historical documents mention important quantities of cotton. Dated to the end of the $12^{\text {th }}$ century, the description of the sack of Qasr Ibrim reports the presence of a large amount of cotton, most probably raw cotton, in the town. We don't know if this cotton was taken from different areas in the town or if it was found already stored in a specific location. However, the fact that it was smoothly taken, transported, and finally sold in Upper Egypt by Shams ad-Daulah, may indicate that the cotton was found already gathered and maybe packed somehow in a storage area. The text does not indicate the specific amount of cotton taken by the Egyptians, but its important quantity is revealed by the expression "sold for a large sum" (Abu Salih the Armenian in Vantini 1975: 328).

Following the enthronement of king Mashkouda a century later, Egypt annexed the provinces of al-Ali and al-Jabal, equivalent to the territory of Lower Nubia (Seignobos 2010). The oath taken by the king in 1276 was reported by an-Nuwayri (d. 1332, in Vantini 1975: 472-474). Based on this early document, the two later authors Ibn al-Furat and al-Maqrizi, indicate the important amount of cotton and dates produced in the area and now belonging to the Sultan, a detail which isn't mentioned by an-Nuwayri. These documents reveal two important pieces of information: first, the large-scale production of cotton and dates in Nubia during the medieval period; second, the existence of taxation imposed by Mashkouda's predecessors on Nubia, which should now be paid by the inhabitants to the Sultan ${ }^{47}$. Once again, no quantity is precisely given in the written sources, but the sheer amount of the harvest must have been substantial enough so the king, and later the Sultan, could impose a tax upon it.

The documentation, while scarce and inviting to caution, sheds light upon a significant cotton production in Lower Nubia during the $12^{\text {th }}$ and $13^{\text {th }}$ centuries, offering an interesting historical pendant to the archaeological data from Qasr Ibrim. The sources 
reveal not only the cultivation of small (but probably numerous) cotton parcels for domestic needs, but also the existence of a tax imposed on parts of the harvest by the Makurite court.

\section{What was cotton's value?}

Both textiles and written sources display the value of cotton in the Nubian medieval society ${ }^{48}$ : archaeological textiles attest its social and economic importance as woven and/or tailored cloths, while historical documents show the value of cotton as raw material.

91 In the visual expression of royal power, silk fabrics replaced cotton cloths as the support of lavish decorations, from the second half of the $10^{\text {th }}$ century CE. However, the combination of later texts with iconography, if a little hazardous, shows that cotton garments were probably also used by the Nubian kings. More convincingly, the cotton garments frequently found in the graves of both administrative and religious dignitaries ${ }^{49}$ prove that it still constituted a large part of the elites' apparel. Cotton tunics, trousers, and caps were for example found in the grave of bishop Timotheos in Qasr Ibrim (Crowfoot 1977), as well as in the burials of several dignitaries in Gebel Adda (Millet 1967, Wozniak \& Yvanez, forthcoming). Since silk was probably the apanage of the royal family, the adoption of these cotton tailored garments can be interpreted as a conscious choice operated by the Nubian medieval elites in order to show their privileged status within society. When a notable was exercising his administrative or religious office, he was wearing the corpora-approved costume illustrated on religious frescos. His everyday wardrobe carried on the sartorial display (Figure 23), by providing him with another way to physically stand out from the neighbouring folk. The form and the light colour of the cotton tunics and trousers created a strong visual contrast with the common people, lightly covered by short loincloths or dressed in dark woollens and leather. 
Figure 23: Commercial transaction scene from Dongola, SW Annex, room 6, $12^{\text {th }} \mathrm{c}$.

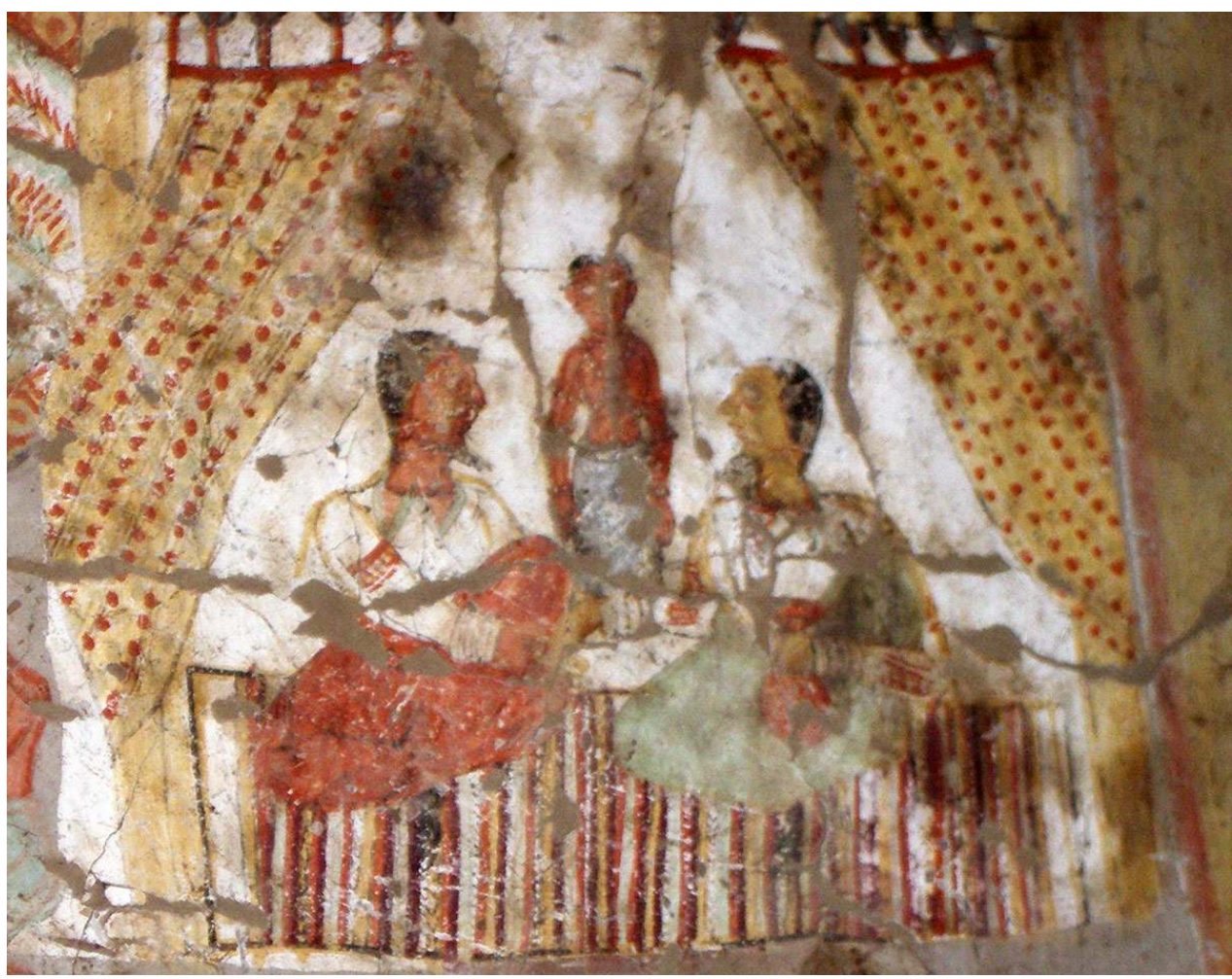

Photo M. Wozniak 2006, courtesy of Stefan Jakobielski/PAM

92 Regarding cotton's value as a raw material, we must once again refer to the description of the sack of Qasr Ibrim and to the later texts dealing with the annexation of al-Ali and al-Jabal provinces (see above). The value of cotton in these documents is two-fold: it appears first as a valuable cash crop and second as an important harvest of large quantity. Both the quality and quantity of cotton production can be taken into consideration to estimate its economic value. Interestingly, it seems that during the medieval period, the raw cotton produced in Nubia was taxed and probably exported to Egypt by the Makurite court. The annexation of the main cotton-producing provinces, al-Ali and al-Jabal, must have been a fruitful economic operation led by the Sultan in order to provide important amounts of raw cotton to the Egyptian market, most probably intended for royal tiraz manufactures. During the $12^{\text {th }}$ and $13^{\text {th }}$ centuries, Egypt was indeed entirely reliant on imported stocks, as it didn't grow significant amounts of cotton itself. Therefore, the importance of Nubia as a potential provider of cotton fibres to the Egyptian market must have been substantial.

\section{Conclusion: Diachronic evolution of cotton cultivation in Sudan and Nubia}

We will conclude this article by a graph showing the evolution of cotton use from its appearance in Sudan to the end of the medieval period (Figure 24). This graph doesn't incorporate all the textile data assembled by the authors, and is only based on a selection of the most representative sites ${ }^{50}$. 
Figure 24: Histogram tracking the evolution of fibre use in Sudan from the Early Meroitic period to the Late Medieval period

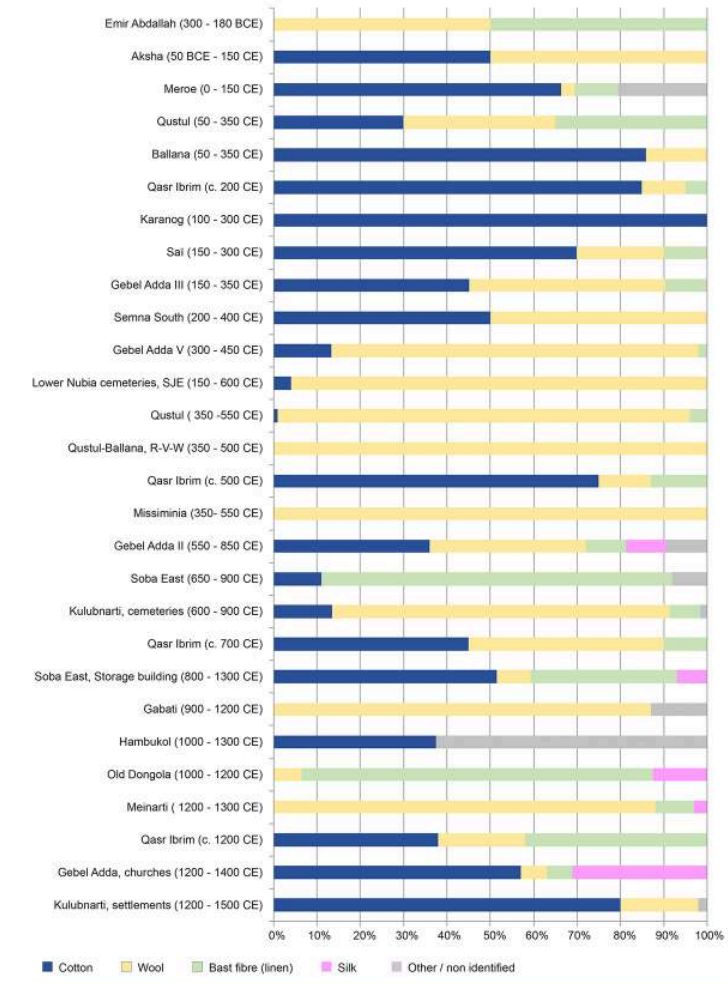

Graph E. Yvanez/M. Wozniak

The only known collection of Early Meroitic textiles comes from Emir Abdallah $\left(3^{\text {rd }}-2^{\text {nd }}\right.$ centuries BCE), in Lower Nubia, where the fabrics are evenly divided between wool and linen. The turn of the modern era, which corresponds to the domestication (?) and spread of larger scale cotton cultivation, marks a sharp evolution in textile manufacture: we now observe rates of cotton between $80 \%$ and $100 \%$ of the total assemblages in Meroe, Qasr Ibrim, Ballana, and Karanog. The Late Meroitic phase and the beginning of the Postmeroitic period (end of the $3^{\text {rd }}$ century and $4^{\text {th }}$ century CE) show growing percentages of wool, especially in Lower Nubia. During the Postmeroitic phase, wool dominates the textile landscape of Qustul, Ballana, and Missiminia, while cotton only continues to play a major role at Qasr Ibrim. In continuity with the Postmeroitic phase, the Early Medieval period (mid- $7^{\text {th }}$ century - end of the $12^{\text {th }}$ century $\mathrm{CE}$ ) is characterised by the strong decline of cotton while wool appears as the main fibre in most of the assemblages: at Qasr Ibrim of course, but also at Kulubnarti and in the cemeteries of es-Sadda and el- $\mathrm{Ar}^{51}$ in the $4^{\text {th }}$ Cataract area (Wozniak, in preparation). Starting in the middle of the $9^{\text {th }}$ century $\mathrm{CE}$, the amounts of cotton and wool appear more balanced in the Qasr Ibrim corpus. The end of the Late Medieval period, from the $14^{\text {th }}$ century CE onwards, shows a new peak in the use of cotton textiles. This feature can be noticed at other Nubian sites, such as Gebel Adda or Kulubnarti. As it is often the case, the lack of data coming from Central Sudanese sites prevent us from drawing general conclusions applicable to the whole Sudanese territory.

The sharp decline of cotton use in Postmeroitic Nubia seems surprising: now sustained by the introduction of the saqia water wheel (Fuller 2015: 42, Wild et al. 2007), the crop 
would have been much easier to grow than before. Irrigation would have been easier and more arable land would have been gained. But this assumption is contradicted by a sharp drop of cotton consumption rates. One hypothesis, brought forward by Dorian Fuller, postulates that cotton was still grown but no longer consumed locally (Fuller 2015). It could have been used instead by the Ballanean authorities as a valuable cash crop to trade with Roman Egypt. Another possibility is that the need for cotton textiles disappeared at the same time as the Meroitic royal power, when Nubian elites turned their attention to their Egyptian neighbours and adopted the Mediterranean costume, composed of woollen tunics and mantles (Wozniak \& Yvanez, forthcoming).

This surprising absence of cotton, lasting over a long period, may also perhaps be related to climatic and environmental changes, brought forward by the Late Antique Little Ice Age (LALIA, $6^{\text {th }} 7^{\text {th }}$ centuries CE). Its consequences on the local economy mustn't be underestimated: "Climatic changes have had - and perhaps still have - their most obvious impacts near the limits, or transition zones, of different climate and vegetation zones. The regions near the thermal or hydrological limit for a certain kind of agricultural or pastoral activity are most sensitive to environmental changes because warmer/colder or dryer/wetter conditions can more easily displace these limits" (Büntgen et al., 2016: 8). The precise impact of LALIA in the Middle Nile Valley has yet to be determined, but the alteration of climatic conditions (not only temperature but also humidity levels) may well have had a direct influence on cotton cultivation in Nubia, where the variety grown was well adapted to a dry environment. In any case, such a sharp change in the local economy was most probably a multi-factorial event involving a combination of environmental, economic and historical conditions.

The higher percentages of cotton fibre visible during the Classic Christian period reflect a return to optimal conditions, climatic but also economic and political, which permitted the reintegration of cotton cultivation on a regional scale. It should be noticed that a substantial part of the crops was probably payed to the Nubian king as a tax, so the quantity of cotton used by the inhabitants themselves must have been necessarily limited. The progressive development of cotton clothing over woollen garments, and their subsequent domination in the textile assemblages of the end of the Late Medieval period, is generally explained by the arrival on the textile market of imported cotton from India (Adams 2010: 163-164). However, as the central power provided the main incentive to grow cotton (for tax purposes and to clothe the elite), the progressive dismantling of the Nubian kingdom into smaller local entities as well as the raising process of land fragmentation, must also have played a major role in the redistribution of market forces.

These questions will find interesting answers as we continue to deepen our understanding of cotton production in the old World. Pushed by the development of new testing methods, such as Strontium Isotope tracing to geo-locate the provenance of the fibres (Bouchaud et al., this volume), ancient textile research will continue to grow and renew our views on cotton production along the Nile, on both sides of the Egypto-Nubian border. 


\section{BIBLIOGRAPHY}

Adams N.K. 1987 - Textile Remains from a Late Temple in Egyptian Nubia. Ars Textrina 8 : 85-124.

Adams N.K. 1989 - Meroitic high fashions: examples from art and archaeology. In : Burstein S.M., Donadoni S. \& Wenig S. (Ed.), Studia Meroitica 1984, Meroitica 10. Berlin, Akademie Verlag : 747-755.

Adams N.K. 2001 - Religious Conversion and Dress Style Repudiation: The Evidence from Qasr Ibrim. In : Ballard Drooker P. (Ed.), Fleeting Identities: Perishable Material Culture in Archaeological Research, Center for Archaeological Investigations Occasional Paper $n^{\circ} 28$. Carbondale, Southern Illinois University : 386-398.

Adams N.K. 2006 - Ideologies in Conflict: The Textiles from the Isis Temple at Qasr Ibrim. In : Schrenk S. (Ed.), Textiles in Situ: their find spots in Egypt and neighboring countries in the $1^{\text {st }}$ Millennium CE. Ann Arbor, University of Michigan : 197-210.

Adams N.K. 2007 - Political Affinities and Economic Fluctuations: the Evidence from Textiles. In : Gillis C. \& Nosh M.-L. (Ed.), Ancient Textiles: production, craft and society: Proceedings of the $1^{\text {st }}$ International Conference on Ancient Textiles. Oxford, Oxbow books : 201-207.

Adams N.K. 2015 - Images of Men in the 'Ethiopian Chamber' in the Isis Temple at Philae: What Were They Wearing?. In : Zach M. (Ed.), The Kushite World. Proceedings of the 11th International Conference For Meroitic Studies, Beiträge zur Sudanforschung 9. Vienna, Verein der Förderer der Sudanforschung : 447-454.

Adams N.K. \& Crowfoot E. 2001 - Varia Romana: Textiles from a Roman Army Dump. In : WaltonRogers P., Jørgensen L.B. \& Rast-Eicher A.R. (Ed.), The Roman Textile Industry and its Influence, a birthday tribute to John Peter Wild. Oxford, Oxbow books : 30-37.

Adams W.Y. 1977 - Nubia, Corridor to Africa. Penguin Books, London.

Adams W.Y. 1996 - Qasr Ibrim. The late Medieval Period. London, Egypt Exploration Society. (EES Excavation Memoir ; 59).

Adams W.Y. 1998 - Kulubnarti II. The artifactual remains. London, Egypt Exploration Society.

Adams W.Y. 1999 - Kulubnarti III. The cemeteries. London, Egypt Exploration Society.

Adams W.Y. 2002 - Meinarti I. The Late Meroitic, Ballana and Transitional Occupation. Oxford, Archaeopress.

Adams W.Y. 2010 - Qasr Ibrim. The Earlier Medieval Period. London, Egypt Exploration Society. (EES Excavation memoir ; 89).

Adams W.Y. \& Adams N.K. 2013 - Qasr Ibrim: The Ballaña Phase. London, Egypt Exploration Society. (EES Excavation memoir ; 104).

Anderson J. 2004 - Excavations at North Kom, Hambukol (Upper Nubia): 1996 and 1997 Seasons. In : Kendall T. (Ed.), Nubian Studies 1998. Boston, Northeastern University : 232-236.

Andersson Strand E. 2015 - The basics of textile tools and textile technology - from fibre to fabric. In : Andersson Strand E. \& Nosch M.-L. (Ed.), Tools, Textiles, and Contexts. Investigating Textile Production in the Aegean and Eastern Mediterranean Bronze Age. Oxford, Oxbow books : 39-60. (Ancient Textiles Series ; 21). 
Andersson Strand E. 2017 - Production and Distribution. In : Heller S.-G. (Ed.), Fashion in the Medieval Ages (500-1450). A Cultural History of Dress and Fashion, vol. 2. London, Berg/Bloomsbury : 29-52.

Arkell A.J. 1955 - A History of the Sudan. From the Earliest Times to 1821. Westport, Greenwood press. Barber E.J.W. 1992 - Prehistoric Textiles: The Development of Cloth in the Neolithic and Bronze Age with Special Reference to the Aegean. Chichester, Princeton University Press.

Baud M. (Ed.) 2010 - Méroé, Un empire sur le Nil, catalogue de l'exposition du Louvre. Paris, Milan, Musée du Louvre, Officina Libraria.

Bergman I. 1975 - Late Nubian Textiles, Scandinavian Joint Expedition 8. Oslo, Scandinavian University Books.

Bouchaud C. 2013 - Exploitation végétale des oasis d'Arabie. Production, commerce et utilisation des plantes. L'exemple de Madâ'in Sâlih (Arabie Saoudite) entre le IV siècle av. J.-C. et le viI ${ }^{\mathrm{e}}$ siècle ap. J.-C. Revue d'Ethnoécologie 4 [online] DOI: 10.4000/ethnoecologie.1217

Bouchaud C., Clapham A., Newton C., Tallet G. \& Thannheiser U. 2018 - Cottoning on to Coton (Gossypium spp.) in Arabia and Africa during Antiquity. In : Mercuri A.M., D'Andrea A.C., Fornaciari R. \& Höhn A. (Ed.), Plants and People in the African Past. Springer [ebook] : 330-426.

Browne G.M. 1991 - Old Nubian Texts from Qasr Ibrim III. London, Egypt Exploration Society.

Bruneau P. 1983 - Le vêtement. Revue d'Archéologie Moderne et d'Archéologie Générale 2 : 139-171.

Büntgen U., Myglan V.S., Charpentier Ljungqvist F., McCormick M., Di Cosmo N., Sigl M., Jungclaus J., Wagner S., Krusic P.J., Esper J., Kaplan J.O., de Vaan M.A.C., Luterbacher J., Wacker L., Tegel W. \& Kirdyanov A.V. 2016 - Cooling and societal change during the Late Antique Little Ice Age from 536 to around 660 AD. Nature Geoscience 9 : 231-236. DOI: 10.1038/NGEO2652

Burckhardt J.L. 1819 - Travels in Nubia. London, J. Murray.

Burke B. 2007 - The Kingdom of Midas and Royal Cloth Production. In : Gillis C. \& Nosh M.-L. (Ed.), Ancient Textiles: production, craft and society: Proceedings of the $1^{\text {st }}$ International Conference on Ancient Textiles. Oxford, Oxbow books : 64-70.

Chowdhury K.A. \& Buth G.M. 1970 - 4,500 Year Old Seeds Suggest that True Cotton is Indigenous to Nubia. Nature $227 / \mathrm{n}^{\circ} 5253: 85-86$.

Chowdhury K.A. \& Buth G.M. 1971 - Cotton seeds from the Neolithic in Egyptian Nubia and the origin of Old World Cotton. Biological Journal of the Linnean Society 3 : 303-312.

Chowdhury K.A. \& Buth G.M. 2005 - Plant Remains from Excavation of Terraces of the Nile at Afyeh, Nubia and Egypt. Purattatva 35 : 154-159.

Clapham A. \& Rowley-Conwy P. 2006a - Rewriting the History of African Agriculture. Planet Earth : 24-26.

Clapham A. \& Rowley-Conwy P. 2006b - Qasr Ibrim's archaeobotany. Egyptian Archaeology 29 : 6-7.

Clapham A. \& Rowley-Conwy P. 2007 - New Discoveries at Qasr Ibrim, Lower Nubia. In : Cappers R. (Ed.), Fields of Change. Proceedings of the $4^{\text {th }}$ International Workshop for African Archaeobotany. Elde, Barkhuis \& Groningen, Groningen University Library : 157-164.

Clapham A. \& Rowley-Conwy P. 2009 - The Archaeobotany of cotton (Gossypium sp. L.) in Egypt and Nubia with special reference to Qasr Ibrim, Egyptian Nubia. In : Fairbairn A. \& Weiss E. (Ed.), From foragers to farmers. Papers in Honour of G. Hillman. Oxford: Oxbow Books : 244-253. 
Crowfoot J.W. 1911 - The Island of Meroe. London, Egypt Exploration Fund. (Archaeological Survey of Egypt ; 19).

Crowfoot E.G. 1977 - The Clothing of a Fourteenth-Century Nubian Bishop. In : Gervers V. (Ed.), Studies in Textile History: In Memory of Harold B. Burnham. Toronto, Royal Ontario Museum : 43-51. Crowfoot G.M. 1931 - Methods of Hand Spinning in Egypt and the Sudan. Halifax, County Borough Museum of Halifax. (Bankfield Museum Notes Second Series ; 12).

Crowfoot G.M. 1955 - The Linen Textiles. In : Barthélemy D. \& Milik J.T. (Ed.), Qumran Cave, Discoveries in the Judean Desert I. Oxford, Clarendon press : 18-38.

Crowfoot G.M. 1961 - The Textiles and Basketry. In : Benoit P., Milik J.T. \& de Vaux R. (Ed.), Les Grottes de Murabba'at, Discoveries in the Judean Desert 2. Oxford, Clarendon press : 52-63.

Edwards D.N. 1996 - Appendix 3. The Meroitic settlement on Tila Island. In : Edwards D.N., The Archaeology of the Meroitic State: new perspectives on its social and political organization. Cambridge Monographs in African Archaeology 38, BAR 640. Oxford, BAR publishing : 106-114.

Edwards D.N. 2004 - The Nubian Past, An Archaeology of Sudan. London, Routledge.

Eide T., Hägg T., Pierce R.H. \& Török L. 1996 - Fontes Historiae Nubiorum, Textual Sources for the History of the Middle Nile Region between the Eight Century B.C. to the Sixth Century A.D., vol. III, From the first to the sixth century A.D. Bergen, University of Bergen.

Fuller D.Q. 2008 - The spread of textile production and textile crops in India beyond the Harappan zone: an aspect of the emergence of craft specialization and systematic trade. In : Osada T. \& Uesugi A. (Ed.), Linguistics. Kyoto, Research Institute for Humanity and Nature : 1-26. (Archaeology and the Human Past Occasional Paper ; 3).

Fuller D.Q. 2014 - Agricultural Innovation and State Collapse in Meroitic Nubia: the Impact of the Savannah Package. In : Stevens C.J., Nixon S., Murray M.A. \& Fuller D.Q. (Ed.), Archaeology of African Plant Use. Walnut Creek, Left Coast Press : 165-177.

Fuller D.Q. 2015 - The Economic Basis of the Qustul Splinter State: Cash Crops, Subsistence Shifts, and Labour Demands in the Post-Meroitic Transition. In : Zach M. (Ed.), The Kushite World. Proceedings of the 11th International Conference For Meroitic Studies, Beiträge zur Sudanforschung 9. Vienna, Verein der Förderer der Sudanforschung : 33-60.

Fuller D.Q. \& Edwards D.N. 2001 - Medieval Plant Economy in Middle Nubia: Preliminary Archaeobotanical Evidence from Nauri. Sudan \& Nubia 5 : 97-103.

Gervers M. 1990 - Cotton and Cotton Weaving in Meroitic Nubia and Medieval Ethiopia. Textile History 21 (I) : 13-30.

Godlewski W., Mahler R. \& Czaja-Szewczak B. 2012 - Crypts 1 and 2 in the Northwest Annex of the Monastery on kom H in Dongola: Report on the Exploration in 2009. Polish Archaeology in the Mediterranean $21: 338-360$.

Griffith F.L. \& Crowfoot G.M. 1934 - On the Early use of Cotton in the Nile Valley. Journal of Egyptian Archaeology 20 : 5-12.

Grzymski K. \& Anderson J. 2001 - Hambukol Excavations 1986-1989, SSEA Publication XVI. Mississauga, Benben Publications.

Hinds M. \& Sakkout H. 1981 - A letter from the governor of Egypt to the King of Nubia and Muqurra concerning Egyptian-Nubian Relations in 141/758. In : Al-Qadi W. (Ed.), Studia Arabica et Islamica. Festschrift für Ihsan Abba. Beirut, American University of Beirut : 209-229. 
Kheir M.H. 1985 - A contribution to a Textual Problem: Ibn Sulaym al-Aswani's Kitab Ahbar alNuba wa l'Maqurra wa-l-Beja wa-l-Nil. Annales Islamologiques 21 : 9-72.

Levin M. \& Pearce E.M. (Ed.) 1998 - Handbook of Fiber Chemistry (2 ${ }^{\text {nd }}$ edition). New York, Marcel Dekker.

Lombard M. 2002 - Études d'économie médiévale : Les textiles dans le monde musulman du VIIe au XIIe s. Paris, Éditions de l'EHESS [ $1^{\text {st }}$ ed. 1987].

Maillot M. 2017 - Un siècle de fouilles archéologiques. In : Collectif, Histoire et Civilisations du Soudan de la Préhistoire à nos jours. Paris, Editions Soleb/Bleu Autour : 446-468.

Martens-Czarnecka M. 2005 - Wall Paintings Discovered in Dongola in the 2004 Season. Polish Archaeology in the Mediterranean $16: 273-284$.

Mayer-Thurman C.C. \& Williams B. 1979 - Ancient Textiles from Nubia: Meroitic, X-Group and Christian Fabrics from Ballana and Qustul. Chicago, Art Institute of Chicago.

Millet N.B. 1967 - Gebel Adda Preliminary Report, 1965-66. Journal of the American Research Center in Egypt $6: 53-63$.

Olofsson L., Andersson Strand E. \& Nosch M.-L. 2015 - Experimental Testing of Bronze Age Tools. In : Andersson Strand E. \& Nosch M.-L. (Ed.), Tools, Textiles, and Contexts. Investigating Textile Production in the Aegean and Eastern Mediterranean Bronze Age. Oxford, Oxbow books : 75-100. (Ancient Textiles Series ; 21).

Osman A. 1982 - The Post-Medieval Kingdom of Kokka: A Means for a Better Understanding of the Administration of the Medieval Kingdom of Dongola. In : Plumley J.M. (Ed.), Nubian Studies: Proceedings of the Symposium for Nubian Studies, Selwyn College, Cambridge, 1978. Warminster-Wilts, Aris \& Phillips : 185-197.

Palmer S.A., Clapham A.J., Rose P., Freitas F.O., Owen B.D., Beresford-Jones D., Moore J.D., Kitchen J.L. \& Allaby R.G. 2012 - Archaeogenomic Evidence of Punctuated Genome Evolution in Gossypium. Molecular Biology and Evolution 29 (8) : 2031-2038.

Pfister R. 1937 - Nouveaux Textiles de Palmyre: Découverts par le Service des Antiquités du HautCommissariat de la République Française dans la nécropole de Palmyre. Paris, Les Éditions d'art et d'histoire.

Rowley-Conwy P. 1989 - Nubia AD 0-550 and the "Islamic" Agricultural Revolution: Preliminary Botanical Evidence from Qasr Ibrim, Egyptian Nubia. Archéologie du Nil Moyen 3 : 131-138.

Ruffini G. 2012 - Medieval Nubia. A social and economic history. New York, Oxford University Press.

Rutschowscaya M.-H. 1986 - Catalogue des bois de l'Égypte copte. Paris, Réunion des Musées Nationaux.

Seignobos R. 2010 - La frontière entre le bilad al-Islam et le bilad al-Nuba : enjeux d'une frontière immobile (VI ${ }^{\mathrm{e}}$-XIII ${ }^{\mathrm{e}}$ siècle). Afriques 2 [published online on 01/03/2010, last consulted 15/05/2019. URL : http://journals.openedition.org/afriques/800. DOI : 10.4000/afriques.800].

Serjeant R.B. 1948 - Material for a History of Islamic Textiles up to the Mongol Conquest. Ars Islamica $13:$ : 75-117

Shinnie P.L. 1967 - Meroe, A Civilization of the Sudan. London, Thames and Hudson. Soudan, Royaumes sur le Nil 1997 - Catalog from the exhibition at the Institut du monde arabe. Paris, Flammarion. 
Spaulding J. 1995 - Medieval Christian Nubia and the Islamic World: a reconsideration of Baqt Treaty. International Journal of African Historical Studies 28 (3) : 577-594.

Timar-Balazsy A. \& Eastop D. 1998 - Chemical Principles of Textile Conservation. London, Betterworth-Heinemann.

Török L. 1988 - Late Antique Nubia, History and Archaeology of the Southern Neighbor of Egypt in the $4^{\text {th }}$ $-6^{\text {th }}$ c. A.D., ANTAEUS 16. Budapest, Archaeological Institute of the Hungarian Academy of Sciences.

Török L. 1990 - The Costume of the Ruler in Meroe: Remark on its origins and significance. Archéologie du Nil Moyen 4 : 151-202.

Troupeau G. 1954 - La description de la Nubie d'al-Uswânî (IV ${ }^{e}-X^{e}$ s.). Arabica 1 : 276-288.

Vantini G. 1975 - Oriental Sources concerning Nubia. Heidelberg, Erich Dinkler / Warsaw, Kasimierz Michalowski.

Vogelsang-Eastwood G. 2001 - Textiles. In : Grzymski K. \& Anderson J. (Ed.), Hambukol Excavations : 79-83.

Walsh R.P.D. 1991 - Climate, hydrology, and water resources. In : Craig G.M. (Ed.), The Agriculture of the Sudan, Oxford Science Publications. Oxford, Oxford University Press : 19-53.

Watson A.M. 1977 - The Rise and Spread of Old World Cotton. In : Gervers V. (Ed.), Studies in Textile History, in Memory of H.B. Burnham. Toronto, Royal Ontario Museum : 355-369.

Welsby D.A. 1998 - Soba II. Renewed excavations within the metropolis of the Kingdom of Alwa in Central Sudan. London, British Museum press. (Memoirs of the British Institute in Eastern Africa ; 15).

Welsby D.A. 2002 - Medieval Kingdoms of Nubia: Pagans, Christians and Muslims in the Middle Nile. London, British Museum press.

Welsby D.A. \& Daniels C.M. 1991 - Archaeological Research at a Medieval Capital on the Blue Nile. London, British Institute in Eastern Africa. (Memoirs of the British Institute in Eastern Africa ; 12).

Wild F.C. 2011 - Fringes and aprons - Meroitic clothing: an update from Qasr Ibrim. In : De Moor A. \& Fluck C. (Ed.), Dress Accessories of the $1^{\text {st }}$ Millennium AD from Egypt. Lanoo, Tielt : 110-119.

Wild J.P. \& Wild F.C. 2006 - Qasr Ibrim: Study Season 2005. Archaeological Textiles Newsletter 43 : 16-19.

Wild J.P. \& Wild F.C. 2008 - Cotton: the New Wool Qasr Ibrim. Study Season 2008. Archaeological Textiles Newsletter 46 : 3-6.

Wild J.P. \& Wild F.C. 2009 - Qasr Ibrim: Study Season 2009. Archaeological Textiles Newsletter 49 : 16-18.

Wild J.P. \& Wild F.C. 2014 - Qasr Ibrim: New Perspectives on the Changing Textile Cultures of Lower Nubia. In : O'Connel E.R. (Ed.), Egypt in the First Millennium AD: Perspectives from New fieldwork. Leuven, Peeters : 71-80. (British Museum publications on Egypt and Sudan ; 2). Wild J.P., Wild F.C. \& Clapham A.J. 2007 - Irrigation and the Spread of Cotton Growing in Roman Times. Archaeological Textiles Newsletter $44: 16-18$.

Wild J.P., Wild F.C. \& Clapham A.J. 2008 - Roman cotton revisited. In : Alfaro C. \& Karali L. (Ed.), Purpurae vestes: il symposium internacional sobre textiles y tintes des Mediterraneo en el mundi antiguo. Valencia, Universitat de València : 145-149. 
Woolley C.L. \& Maciver D.R. 1910 - Karanog: The Romano-Nubian cemetery, Eckley B. Coxe Junior Expedition to Nubia, vol. 4. Philadelphia, Pennsylvania University Museum.

Wozniak M.M. 2013 - Iconographie des souverains et des dignitaires de la Nubie chrétienne : les vêtements d'apparat. Doctoral thesis (unpublished). Université Paris IV-Sorbonne.

Wozniak M.M. in preparation - Textiles from the 4th Cataract: contribution to the study of textile production and social practices in Late Antique and Medieval Sudan.

Wozniak M.M. \& Czaja B. forthcoming - Contribution to the Study of the Textiles from Meinarti (Medieval Nubia).

Wozniak M.M. \& Yvanez E. forthcoming - Changing textiles - shifting identities? Costume and political allegiance in Late Antic Nubia. In : Hallman A. (Ed.), Outward Appearance vs. Inward Significance: Addressing Identities through Attire in the Ancient World. Chicago, Oriental Institute. (Oriental Institute Series ; 15).

Yadin Y. 1963 - The Finds from the Bar-Kokhba Period in the Cave of Letters. Jerusalem, The Israel Exploration Society.

Yvanez E. 2015 - De la Fibre à l'Étoffe. Archéologie, production et usages des textiles de Nubie et du Soudan anciens à l'époque méroïtique. Doctoral thesis (unpublished), Université de Lille III-Charles de Gaulle.

Yvanez E. 2016a - Spinning in Meroitic Sudan. Textile Production Implements from Abu Geili. Dotawo, a journal for Nubian studies $3: 153-178$.

Yvanez E. 2016b - Textiles and funerary rituals. The wrapping of offerings at Meroe and elHobagi. Sudan \& Nubia $20: 75-81$.

Yvanez E. 2018a - Clothing the elite? Patterns of textile production and consumption in ancient Sudan and Nubia. In : Ulanowska A., Siennicka M. \& Grupa M. (Ed.), Dynamics and Organisation of Textile Production in Past Societies in Europe and the Mediterranean, Fasciculi Archaeologiae Historicae 31. Lodz, Polska Akademia Nauk, Instytut Archeologii i Etnologii : 81-92.

Yvanez E. 2018b - Se vêtir à Gebel Adda. Nouvelles Perspectives de recherche sur l'identité culturelle en Nubie méroïtique. Route de l'Orient, hors série n³ 3 : 103-123.

Yvanez E. forthcoming - Textiles activities in context: an example of craft production in Meroitic Sudan. In : Onderka P. (Ed.), $12^{\text {th }}$ International Conference for Meroitic Studies, Conference proceedings, Prague National Museum, 5-9th September 2017.

Yvanez E., Murillo M.-L., Francigny V. \& De Voogt A. forthcoming - Cultural interconnections of textile craft and burial practices in Early Medieval Sai (Sudan). Archaeological Textiles Review.

\section{APPENDIXES}

\section{Bibliographical references of sites quoted in the text with textile related finds}

Abka, Datti: Bergman I. 1975 - Late Nubian Textiles, Scandinavian Joint Expedition 8. Oslo, Scandinavian University Books.

Abu Geili / Saqadi: Crawford O.G.S. \& Addison F. 1951 - Abu Geili and Saqqadi and Dar elMek, The Wellcome Excavations in the Sudan, vol. 3. London, Oxford University Press.

Abu Simbel, cemetery 214: Näser C. 1999 - Cemetery 214 at Abu Simbel North. Non Elite Burial Practices in Meroitic Lower Nubia. In Welsby D.A. (ed.), Recent Research in Kushite History and Archaeology, BMOP 131. London, British Museum press: 19-28. 
Aksha: Vila A. 1967 - Aksha II, le cimetière méroïtique d'Aksha. Paris, CNRS.

Ashkeit: Bergman I. 1975 - Late Nubian Textiles, Scandinavian Joint Expedition 8. Oslo, Scandinavian University Books.

Arminna West: Trigger B.G. 1967 - The Late Nubian Settlement at Arminna West, Pennsylvanian-Yale Expedition to Egypt $n^{\circ} 2$. New Haven-Philadelphia, Peabody Museum.

Ballana/Qustul: Mayer-Thurman C.C. \& Williams B. 1979 - Ancient Textiles from Nubia: Meroitic, X-Group and Christian Fabrics from Ballana and Qustul. Chicago, Art Institute of Chicago.

Berber: Berber: Unpublished objects, personal communication from Mahmoud Suleiman Bashir.

Dongola: Godlewski W., Mahler R. \& Czaja-Szewczak B. 2012 - Crypts 1 and 2 in the Northwest Annex of the Monastery on kom H in Dongola: Report on the Exploration in 2009. Polish Archaeology in the Mediterranean 21: 338-360.

el-Ar: Longa, A. 2010 - 'The El-Ar P1 Cemetery (Fourth Cataract, Sudan)', Polish Archaeology in the Mediterranean 19, 420-427; ead. 2012. 'Excavations in 2009 in the environs of El-Ar village (Fourth Cataract region, Sudan)', Polish Archaeology in the Mediterranean 21, 393-398; ead. 2014. 'Cemetery P1 in El-Ar. Part I. An Archaeological Report', Gdansk Arachaeological Museum African Reports 11, 67-72.

el-Hassa: Unpublished material, objects studied by E. Yvanez in 2012 and awaiting publication in the future site's monograph published by Vincent Rondot, René-Pierre Dissaux and Giorgio Nogara.

el-Sadda: Osypinski P. 2007 - "Es-Sadda 1. Excavations of a post-Meroitic Cemetery (Two Seasons)", Polish Archaeology in the Mediterranean 17, 348-363; id. 2010 - "On The Polish Concession (Hamadab Dam Rescue Project) January-February 2007", Polish Archaeology in the Mediterranean 19, 435-447.

Emir Abdallah: Alfaro C. 1983 - Estudio de los fragmentos de tejido. In Fernandez V.M., La Cultura Alto-Meroitica del Norte de Nubia. Unpublished doctoral thesis, Universidad Complutense de Madrid Facultad de Geografía e Historia: 1353-1366.

Gabati: Edwards D.N. 1998 - Gabati, A Meroitic, post-meroitic and medieval cemetery in central Sudan, vol. 1, SARS publication $n^{\circ} 3$, BAR International Series 740. Oxford, BAR publishing.

Gamai/Gammai: Bates O. \& Dunham G. 1927 - Excavations at Gammai, Varia Africana IV. Cambridge, Peabody Museum of Harvard University.

Gebel Adda: Crowfoot E.G. 1977 - The Clothing of a Fourteenth-Century Nubian Bishop. In Gervers V. (ed), Studies in Textile History: In Memory of Harold B. Burnham. Toronto, Royal Ontario Museum: 43-51; Vogelsang-Eastwood G. 1993 - Pharaonic Egyptian Clothing. Leiden, Brill: 33-34, 49, pl. 17; Yvanez E. 2018 - Se vêtir à Gebel Adda. Nouvelles Perspectives de recherche sur l'identité culturelle en Nubie méroïtique. Route de l'Orient, hors série $\mathrm{n}^{\circ} 3$ : 103-123.

Hamadab: Unpublished material, objects studied by E. Yvanez in 2019 and awaiting publication in the future site's monograph published by Pawel Wolf (German Archaeological Institute). Wolf P. \& Nowotnick U. 2006 - Hamadab - A Meroitic Urban Settlement, Excavations 2001-2003. Archéologie du Nil Moyen 10: 257-272.

Hambukol: Anderson J. 2004 - Excavations at North Kom, Hambukol (Upper Nubia): 1996 and 1997 Seasons. In Kendall T. (ed.), Nubian Studies 1998. Boston, Northeastern University: 232-236; Grzymski K. \& Anderson J. 2001 - Hambukol Excavations 1986-1989, SSEA Publication XVI. Mississauga, Benben Publications; Vogelsang-Eastwood G. 2001 Textiles. In Grzymski K. \& Anderson J. (eds), Hambukol Excavations: 79-83. 
Karanog: Woolley C.L. \& Maciver D.R. 1910 - Karanog: The Romano-Nubian cemetery, Eckley B. Coxe Junior Expedition to Nubia, vol. 4. Philadelphia, Pennsylvania University Museum.

Kassinger Bahri: Maik J. 2007 - Textiles from a late fifth-century Post-Meroitic cemetery in Kassinger Bahri (Sudan). Gdańsk Archaeological Museum African Reports 5: 97-102; Fisher C.-H. 2007 - Analysis of Dyestuffs from the Textiles of a Post-Meroitic Burial. Gdańsk Archaeological Museum African Reports 5: 124-128.

Kulubnarti: Adams W.Y. 1998 - Kulubnarti II. The artifactual remains. London; Id.,1999. Kulubnarti III. The cemeteries. London, SARS.

Meinarti: Wozniak M. \& Czaja B. forthcoming - Contribution to the Study of the Textiles from Meinarti (Medieval Nubia).

Meroe: Griffith F. Ll. \& Crowfoot G.M. 1934 - On the Early Use of Cotton in the Nile Valley. Journal of Egyptian Archaeology 20: 5-12; Bradley R.J. \& Shinnie P.L. (eds.) 1980 The Capital of Kush I, Meroe Excavations 1965-1972, Meroitica 4. Harrassowitz Verlag, Wiesbaden; Shinnie P.L. \& Anderson J.R. 2004 - The Capital of Kush II, Meroë Excavations 1973-1984, Meroitica 20. Harrassowitz Verlag: Wiesbaden; Yvanez E. 2016 - Textiles and funerary rituals. The wrapping of offerings at Meroe and el-Hobagi. Sudan \& Nubia, Sudan and Nubia 20: 75-81.

Missiminia: Vila A. 1984 - La nécropole de Missiminia. III : Les sépultures ballanéennes, PAVN 14. Paris, CNRS.

Mouweis: Unpublished material, objects studied by the author in 2019 and awaiting publication by E. Yvanez in the future site's monograph published by Marie Millet, Musée du Louvre.

Qasr Ibrim: Adams N.K. 1981 - Textile finds at Qasr Ibrim. Nyame Akuma 18: 6-8; Idem 1986 - Textile Finds at Qasr Ibrim, 1986. Archaeological Textiles Newsletter 3: 10; Idem 1987 - Textile Remains from a Late Temple in Egyptian Nubia. Ars Textrina 8: 85-124; Idem 1989 - Meroitic high fashions: examples from art and archaeology. Meroitica 10: 747-755; Idem 1996 - Textile Materials and Weaves: Dress and Ornamentation. In W. Y. Adams, Qasr Ibrim. The Late Medieval Period, EES Excavation Memoir 59. London, Egypt Exploration Society: 160-170; Idem 1996 - Sacred textiles from an ancient Nubian temple. In Collectif, Sacred and Ceremonial Textiles, Proceedings of the Textile Society of America Biennial Symposium. Chicago Art Institute of Chicago: 259-268; Idem 1998 Ancient Lace of Nubia and the Sudan : A Unique Decorative Tradition. Cahiers de Recherche de l'Institut de Papyrologie et d'Égyptologie de Lille 17/3 : 17-25; Idem 2001 Religious Conversion and Dress Style Repudiation: The Evidence from Qasr Ibrim. In Ballard Drooker P. (ed), Fleeting Identities: Perishable Material Culture in Archaeological Research, Center for Archaeological Investigations Occasional Paper $\mathrm{n}^{\circ} 28$. Carbondale, Southern Illinois University: 386-398; Idem 2006 - Ideologies in Conflict: The Textiles from the Isis Temple at Qasr Ibrim. In Schrenk S. (ed.), Textiles in Situ: their find spots in Egypt and neighboring countries in the $1^{\text {st }}$ Millennium CE. Ann Arbor, University of Michigan: 197-210; Idem 2007 - Political Affinities and Economic Fluctuations: the Evidence from Textiles. In Gillis C. \& M.-L. Nosh (eds.), Ancient Textiles: production, craft and society: Proceedings of the $1^{\text {st }}$ International Conference on Ancient Textiles. Oxford, Oxbow books: 201-207; Adams N.K. \& Crowfoot E. 2001 - Varia Romana: Textiles from a Roman Army Dump. In Walton-Rogers P., Jǿrgensen L.B. \& Rast-Eicher A. (eds.), The Roman Textile Industry and its Influence, a birthday tribute to John Peter Wild. Oxford, Oxbow books: 30-37; Adams W.Y. 1996 - Qasr Ibrim. The late Medieval Period, EES Excavation Memoir 59. London, Egypt Exploration Society; Idem 2010 - Qasr Ibrim. The Earlier Medieval Period, EES 
Excavation memoir 89. London, Egypt Exploration Society; Adams W.Y. \& Adams N.K. 2013 - Qasr Ibrim: The Ballaña Phase, EES Excavation memoir 104. London, Egypt Exploration Society; Crowfoot E. 1984 - Openwork Fringes from Qasr Ibrim. Meroitic Newsletter 23: 10-16; Idem 2011 - Qasr Ibrim: the Textiles from the Cathedral Cemetery. London, Egypt Exploration Society; Granger-Taylor H. 2008 - A fragmentary Roman Cloak, probably of the 1st C. CE and off-cuts from other similar cloaks. Archaeological Textiles Newsletter 46: 6-16; Wild F. 2009 - Qasr Ibrim: a correction. Archaeological Textiles Newsletter 49: 19; Idem 2011 - Fringes and aprons - Meroitic clothing: an update from Qasr Ibrim. In De Moor A. \& Fluck C. (eds.), Dress Accessories of the $1^{\text {st }}$ Millennium AD from Egypt. Lanoo, Tielt: 110-119; Wild J.P. \& Wild F.C. 2006 - Qasr Ibrim: Study Season 2005. Archaeological Textiles Newsletter 43: 16-19; Idem 2008 - Cotton: the New Wool. Qasr Ibrim Study Season 2008. Archaeological Textiles Newsletter 46: 3-6; Idem 2009 - Qasr Ibrim: Study Season 2009. Archaeological Textiles Newsletter 49: 16-18.

Sahaba: Bergman I. 1975 - Late Nubian Textiles, Scandinavian Joint Expedition 8. Oslo, Scandinavian University Books.

Saï: Yvanez E. 2012 - Les textiles des nécropoles méroïtiques de Saï. Cahiers de Recherche de l'Institut de Papyrologie et d'Égyptologie de Lille 29: 331-344.

Semna Sud: Zabkar L.V. \& Zabkar J.J. 1982 - Semna South. A Preliminary Report on the 1966-68 Excavations of the University of Chicago Oriental Institute Expedition to Sudanese. Journal of the American Research Center in Egypt 19: 7-50.

Serra Est, Nag' Shirfadik: Bergman I. 1975 - Late Nubian Textiles, Scandinavian Joint Expedition 8. Oslo, Scandinavian University Books.

Shabloul: Randall-MacIver D. \& Wooley C.L. 1909 - Areika, Eckley B. Coxe Junior Expedition to Nubia, vol. 1. Philadelphia, Pennsylvania University Museum.

Soba: Welsby D.A. 1998 - Soba II. Renewed excavations within the metropolis of the Kingdom of Alwa in Central Sudan, Memoirs of the British Institute in Eastern Africa 15. London, British Museum press; Welsby D.A. \& Daniels C.M. 1991 - Archaeological Research at a Medieval Capital on the Blue Nile, Memoirs of the British Institute in Eastern Africa 12. London, British Institute in Eastern Africa.

Wadi es-Seboua: Emery W.B. \& Kirwan L.P. 1935 - The Excavations and Survey between Wadi es-Sebua and Adindan, 1929-1931. Cairo, Government press.

\section{NOTES}

1. Translation: Bostock J. 1855. The Natural History, Pliny the Elder. London. [available online at www.perseus.tufts.edu, accessed on 12/11/2018]. See also Eide et al. (1996), Fontes Historiae Nubiorum III: $\mathrm{n}^{\circ} 203,874$.

2. Textile samples from Karanog and Meroe were sent to the Shirley Institute of Cotton Research (Manchester), where they were examined and tested by Dr. A.J. Turner and Miss G.G. Clegg of the Research Laboratories of the British Cotton Industry Research Association. The fibres were examined with a microscope under polarised light, then measured (fibre diameter and weight). Meroe's samples were previously examined by botanist R.E. Massey, first at the Shambat Research Farm in Khartoum and then at the Kew Royal Botanical Gardens. The results were communicated through the copy of letter's excerpts in Griffith \& Crowfoot 1934.

3. Until the introduction of cotton in Meroitic Sudan, ancient textiles were predominantly made of linen and wool, with the possible addition of wild plant fibres and animal hair. This last aspect remains undocumented. Cotton, linen and wool continued to dominate the textile landscape of the region in varying degrees until modern times. 
4. For a general introduction to Meroitic history and archaeology, see Edwards 2004: 141-181, Baud 2010.

5. This body of material was the object of a doctoral dissertation (unpublished), see Yvanez 2015.

6. The archaeobotanical corpus of Qasr Ibrim is well known compared to the rest of Sudan and Nubia. It was published in several articles, i.e. Rowley-Conwy 1989 and Clapham \& Rowley-Conwy 2006a, 2006b, 2007, 2009.

7. With other crops such as sorghum and pearl millet. For its adoption in Meroitic Sudan, see Fuller 2014.

8. An extensive bibliography for the Qasr Ibrim textiles is quoted in Appendix 1. See also the following publications by N.K. Adams and those of John Peter and Felicity Wild (Wild \& Wild 2006, 2008, 2009, 2014).

9. The description level of each entry depends on the finesse of the site's inventory and the current accessibility of the collection.

10. The textiles from Qasr Ibrim are the subject of an ongoing doctoral project led by Sarah Hitchens at the Bolton Museum and the University of Liverpool.

11. The present graph represents some of the most representative groups of Meroitic textiles, from the extensive database assembled by the author. The data was collected during study stays in diverse museums as well as through the published bibliography (excavation reports, catalogues, scholarly articles, etc.). For this reason, the coverage of the different textile corpora is very unequal, depending on our access to collections and level of details of each publication. Similarly, we do not dispose of detailed inventories for every site, preventing us from adding any numerical data to the graph. We therefore chose to illustrate the proportions of fibre use through percentages instead of numerical data, so the general tendency becomes well visible despite these disparities.

12. The reader can find the respective bibliography of each site quoted in the text in Appendix 1.

13. Among the whole Meroitic textile corpus, very few textiles were subjected to radiocarbon dating. The chronological attributions reported in this article are the one given by respective archaeologists, mainly based on funerary and ceramic typologies.

14. The hydrological situation in Sudan varies from a hyper-arid climate in Lower Nubia to a tropical rainy climate in the South. Seemingly arid regions such as the Island of Meroe are also subject to seasonal rain falls (Walsh 1991: 19-25).

15. We can wonder as to the reason of this divide. No turned-wood spindle whorl has ever been found in Central Sudan, maybe due to unfavourable conservation conditions. But while the Nubian corpus counts wooden, bone, and baked clay specimens, none of them belong to the group of standardised ceramic spindle whorls from Central Sudan (see below) either. The technological division therefore seems to hold true, and will be the subject of further study.

16. Their exact number cannot be calculated, as the most numerically important groups have not been preserved and published in their entirety.

17. Only several trenches and text excavations have been conducted in the living quarters of the city. Further excavations would presumably reveal a much larger corpus. The author Elsa Yvanez is currently engaged in reviewing the tools discovered during Jane Humphris's excavation of a Meroitic iron production site (UCL-Qatar project).

18. The hundreds of spindle whorls discovered at Qasr Ibrim are in part stored in the British Museum, where they are currently being reexamined by Sarah Hitchens in the framework of her $\mathrm{PhD}$, see note 10 .

19. This categorisation remains very general. Experimental testing would be necessary to determine the quality of the final product, depending on the type of spindle whorl and the cotton quality of the time. Such work have already been conducted by CTR for wool and flax yarns on the basis of Bronze Age finds from the Eastern Mediterranean, but the method remains untested 
on Sudanese material (for a detailed report of the method and results achieved by the Tool and Textiles - Texts and Contexts project, see Olofsson et al. 2015 and Andersson Strand 2015).

20. Many wooden spindle whorls from Qasr Ibrim seem to have received a coat of a black resinous substance (John-Peter Wild and Sarah Hitchens, personal communication).

21. The localisation of the historical battles mentioned in the Ezana inscription in the Butana or at the junction between the Atbara and the Nile was proposed by Lászlo Török (Török 1988: 33-36).

22. The development of Strontium Isotopes tracing in archaeology opens new avenues of research for the geolocalisation of past cotton cultures (while still remaining silent on the domestication process). The possible application of this method in Sudan remains to be tested.

23. The corpus from Karanog is both very well preserved and very diverse in nature. We would like to thank the team of the University of Pennsylvania Museum of Archaeology and Anthropology, particularly Dr. Jennifer Houser-Wegner, for facilitating our study of the material.

24. The typology of Nubian textile technical characteristic can be found with detailed explanations in Bergman 1975: 28-39, fig. 51: 50.

25. British Museum EA71854, online collection database accessed 04.01.2019 [https:// www.britishmuseum.org/research/collection_online]

26. This fashion was reported by Agatharchides, and later copied by Diodorus Sicilus in the $2^{\text {nd }} c$. CE: "As to clothing, some of them have none at all, but live naked all the time [...] Some also use the hides of their animals, others cover the body as far as the waist with girdles which they plait from the hair of the animals [...]". Bibliotheca historica, book 3, chapter 8-9.

27. Very few non-elite burial grounds or settlements have been excavated (Maillot 2017). Several sites have shown small signs of wool, leather and wild plant fibres used for clothing and shroud, but the evidence is too scarce to establish clear tendencies (Yvanez 2018a).

28. As defined by Philippe Bruneau (Bruneau 1983: 156).

29. For a discussion of selected examples of male and female elite garments, see Wild 2011 and Yvanez 2018a.

30. For a critical assessment of the historical value of Ezana's inscription, see Török 1988: 33-36.

31. I would like to express all my gratitude to David N. Edwards who accepted to share with me all the archival data pertaining to textile manufacture on the site for the preparation of an upcoming article (Yvanez forthcoming). For a general description of the site, see Edwards 1996.

32. See also Hinds \& Sakkout 1981, Spaulding 1995, Welsby 2002: 68-73.

33. Recent archaeobotanical analyses conducted in Banganarti and Selib have not provided so far any new attestations of cotton cultivation (personal communication of Prof. Bogdan Zurawski (Polish Academy of Sciences), Director of the Banganarti and Selib missions).

34. Another phenomenon for the degradation of cotton fibres is the mixed weaving of different fibres - animal and vegetal - for warp and weft. It appears that animal "eats" vegetal. For example, some shrouds from et-Tereif (BM, EA 77366, wool and cotton) or Gebel Adda (ROM 973.24.3420, silk and flax).

35. Nettie K. Adams mentions 23432 pieces found during the 11 weeks of the 1980 excavation season (Adams 1996: 160).

36. Cotton textiles were mentioned in Adams 2002: 89, but a recent reexamination of the fabrics in January 2017 in the Sudan National Museum revealed a majority of woollen textiles; not one single cotton textile was identified in the assemblage (Wozniak \& Czaja forthcoming).

37. The database of medieval textiles from Sudan will substantially grow with the integration of the fabrics found in the $4^{\text {th }}$ Cataract area where numerous salvage excavations were conducted in the last years (the material awaits publication). However, the recent examination by one of the authors of textiles from the sites of el-Ar, Shemkhiya, es-Sadda, and Hagar el Beida, as well as few fabrics from et-Tereif, confirms the clear prevalence of woollens. 
38. Travellers' descriptions from the $19^{\text {th }}$ century mention very simple domestic looms, set on few round sticks (see Burckhardt 1819: 253).

39. A small number of ceramic spindle whorls was recovered from Qasr Ibrim, but the artefacts were mostly dated to the Post-Christian period $\left(16^{\text {th }}-18^{\text {th }}\right.$ century CE).

40. Located in Middle Nubia, along the Third cataract.

41. This locality is in turn identified by Burckhardt with the Dar Mahas (Burckhardt 1819: 495 and 523, note 9).

42. Many thanks to Charlène Bouchaud for this valuable observation. For more information about oasian agricultural system, see Bouchaud 2013.

43. Unfortunately, no picture of a cotton specimen of trapezoidal loincloth is available in the published documentation. We have therefore chosen to illustrate this specific garment type by the woollen example from Ashkeit, found in situ on a skeleton and dated to the Postmeroitic / Early Christian period (Bergman 1975: 76, pl. 5.1, pl. 20).

44. 23 occurrences were identified in total from both cemeteries. However, the partition between cotton and wool pieces isn't precisely indicated in the publication.

45. Only one piece identified for the Early Christian Period.

46. Unpublished, ROM 973.24.3481.

47. Would it be possible then that the cotton found at Ibrim by Egyptian troops a century earlier constituted a kind of tax in nature destined to be paid to the Makurite court? For the taxation question, see Ruffini 2012: chap. 7.

48. Very scarce written sources deal with textiles as gift exchange in a political and diplomatic context, in the Egyptian sphere. They mostly mention linen fabrics during the Early Christian period and silks from the $12^{\text {th }}$ century onward (Wozniak 2013: chap. 11). It would be very instructive to see if cotton cloths are also mentioned in the Qasr Ibrim Arab documentation.

49. The higher frequency of linen cloths in these graves should be noted. It is tempting to see flax as an indicator of religious (more precisely) monastic identity (see for example the crypt of the Monastery Annex in Old Dongola). These preliminary observations await to be confronted in the near future to the analyses of the textiles from the monastic complex of Ghazali.

50. The reader will find the site's bibliographical references in Appendix 1. As for the other graphs included in the present article, the data comes from several studies: some previously published in past research since the 1910s, and some more recently assembled by the authors. The level of documentation is therefore quite unequal, from rough estimations to detailed inventories. For this reason, it has proved impractical to provide the reader with a table listing the numerical data behind the proportions given here. The graph is therefore to be used as a visual aid rather than an exhaustive tool. We hope to complete our investigations in the following years, to be able to refine this diachronic picture. The use of textile fibres has also been tracked in Nettie Adams's pioneering study at Qasr Ibrim, which data are included here. See Adams 2007: 203, fig. 33.2.

51. The data from these 2 sites is currently under observation and remains untreated in its entirety, therefore doesn't figure in the graph. 


\section{ABSTRACTS}

Since Pliny the Elder described the "wool-bearing trees" of Aethiopia in his Natural History, the cultivation of cotton has been a well-known aspect of the textile production of ancient Sudan. It was confirmed during the first decades of Sudanese archaeology by the discovery of many cotton textiles found in Meroe and Lower Nubia, and more recently completed by several archaeobotanical studies conducted in the same regions. The aim of this article is to survey the whole span of data pertaining to cotton in ancient Sudan, collecting information from different sources and chronological periods, so as to trace the evolution of cotton production from the Meroitic to the medieval times. New discoveries have led to a regain of interest for textile research in this part of the world, which will help us contextualize cotton cultivation within the wider framework of clothing and social display, as well as textile craft and the organization of the economy. This multi-disciplinary approach will highlight the important role of Sudan and Nubia in the development of cotton production and exchange in the ancient world.

Depuis que Pline l'Ancien mentionna « les arbres à laine » d'Éthiopie dans son Histoire Naturelle, la culture du coton est un aspect bien connu de la production textile du Soudan ancien. Celle-ci fut confirmée dès le début de l'archéologie soudanaise par la découverte de nombreux tissus de coton à Méroé et en Basse Nubie, et complétée plus récemment par plusieurs études archéobotaniques menées dans les mêmes régions. L'objectif de cet article est de rassembler l'ensemble des données disponibles traitant du coton dans le Soudan ancien, collectant des informations issues de différentes sources et périodes chronologiques, afin de tracer l'évolution de la production cotonnière de l'époque méroïtique à l'époque médiévale. De nouvelles découvertes ont amené à un certain renouveau des études textiles dans cette partie du globe, nous permettant de contextualiser la culture du coton dans un cadre plus large, couvrant l'habillement et la construction d'une image sociale, ainsi que l'artisanat textile et l'organisation économique. Cette approche multidisciplinaire permettra de valoriser le Soudan et la Nubie antiques comme d'importants acteurs dans le développement de la production et de l'échange du coton dans le monde ancien.

\section{INDEX}

Mots-clés: coton, archéologie, textiles, Soudan, Nubie, costume, ancienne économie

Keywords: cotton, archaeology, textiles, Sudan, Nubia, costume, ancient economy

\section{AUTHORS}

\section{ELSA YVANEZ}

Centre for Textile Research, University of Copenhagen. ORCiD 0000-0002-0934-8367

Elsa Yvanez is an archaeologist specialised in the textile production of Antique Sudan and Nubia, in the chaîne opératoire and economic significance of spinning and weaving, as well as in the use of textiles for clothing and burial. Marie Skłodowska-Curie fellow at the Centre for Textile Research (UCPH), she is leading the TexMeroe project with the support of the European Union's Horizon 2020 research and innovation programme under the grant agreement $n^{\circ} 743420$.

www.texmeroe.com, @texmeroe

elsa.yvanez@gmail.com 


\section{MAGDALENA M. WOZNIAK}

Institute of Mediterranean and Oriental Cultures, Polish Academy of Sciences. ORCiD 0000-0003-3551-2762.

Magdalena M. Wozniak is an archaeologist specialised in textile production and cloth consumption of medieval Sudan, with a focus on the relationship between costume and identity. She is conducting research on the project Nubian Textiles: craft, trade, costume and identity in the medieval kingdom of Makuria, which has received funding from the National Science Centre, Poland (Polonez Grant UMO 2015/19/P/HS3/02100) and from the European Union's Horizon 2020 research and innovation programme under the Marie Skłodowska-Curie grant agreement $\mathrm{n}^{\circ} 665778 \mathrm{http}$ //centrumnubia.org/en/projects/nubian-textiles mwozniak@iksio.pan.pl 